\title{
6 The Arsakid Empire
}

\section{Introduction: The 'Second Iranian Empire'}

The Arsakid Empire, also known as the Parthian Empire, was a vast entity stretching across central and western Asia that grew out of a small provincial state at the intersection of the Seleukid Empire and the Eurasian steppe. ${ }^{1}$ Its ruling Arsakid dynasty, supported by a Parthian aristocracy, lasted for nearly 500 years. It rose in the mid-third century всE and eventually supplanted Seleukid control in Mesopotamia and Iran, where it came to interact with neighbors from Rome, to the Kushans, to China, before falling to upstart Sasanian successors, who had consolidated power in the Iranian highlands.

Despite its pivotal position, scale, and longevity, historical scholarship on the Arsakid Empire and the Parthian cultural logics that it carried with it as it expanded has been far less extensive than that on either its Mediterranean or East Asian neighbors, or its Iranian predecessors and successors. Sources have been a central hindrance. ${ }^{2}$ There is little material preserving an emic (internal) perspective on Arsakid history, which has led to a reliance on exogenous sources as well as those written hundreds of years later, chiefly by hostile Roman, dismissive Sasanian, or distant Chinese authors. ${ }^{3}$ The source problems are not confined to textual material. Parthian-period archaeology was long confined to excavations of a small number of urban sites, providing only shadowy evidence of broader practices across Arsakid space. ${ }^{4}$ At the same time, the traditional reluctance to incorporate the Arsakid

1 The term 'Arsakid' comes from the name of the ruling dynasty, after the eponymous founder Arsakes. The term 'Parthian' is a geographic, linguistic, and ethnic term derived from the Achaemenid satrapy Parthava (Parthyene), which took on an ethnic meaning in the Roman sources and came to describe an empire far beyond the satrapy. Contemporary scholarship has increasingly adopted the term 'Arsakid' to describe the dynastic period. This choice has been defended as a way of avoiding the ethnic implications of the term 'Parthian,' while at the same time bringing the period into scholarly norms for the study of Iranian empires, which rely on dynastic chronologies. There has been, however, a hesitation to abandon the term 'Parthian,' and the term seems to be settling into a new meaning as "the comprehensive term ... applied to the various and complex cultural manifestations in the countries that fell under Arsacid rule” (Invernizzi 2011, 189). See also Hauser 2012, 1001-1003; de Jong 2013a, 147-148.

2 On sources for the study of economy, see Wiesehöfer, ch. 11, this volume.

3 Boyce 1983; Widengren 1983 provide an overview of transmitted texts from Parthian and Sasanian perspectives. For treatments of source material within regional or evidentiary frameworks, see contributions in Wiesehöfer 1998. For a recent compendium of textual sources, see Hackl, Jacobs, and Weber 2010.

4 The most significant excavations are discussed in Hauser 2012, 1005-1011.

Note: My thanks to Matthew Canepa for his helpful comments on an earlier draft of this chapter.

Ә Open Access. (c) 2020 Lara Fabian, published by De Gruyter. (c) BY-NC-ND This work is licensed under the Creative Commons Attribution-NonCommercial-NoDerivatives 4.0 License.

https://doi.org/10.1515/9783110607741-008 


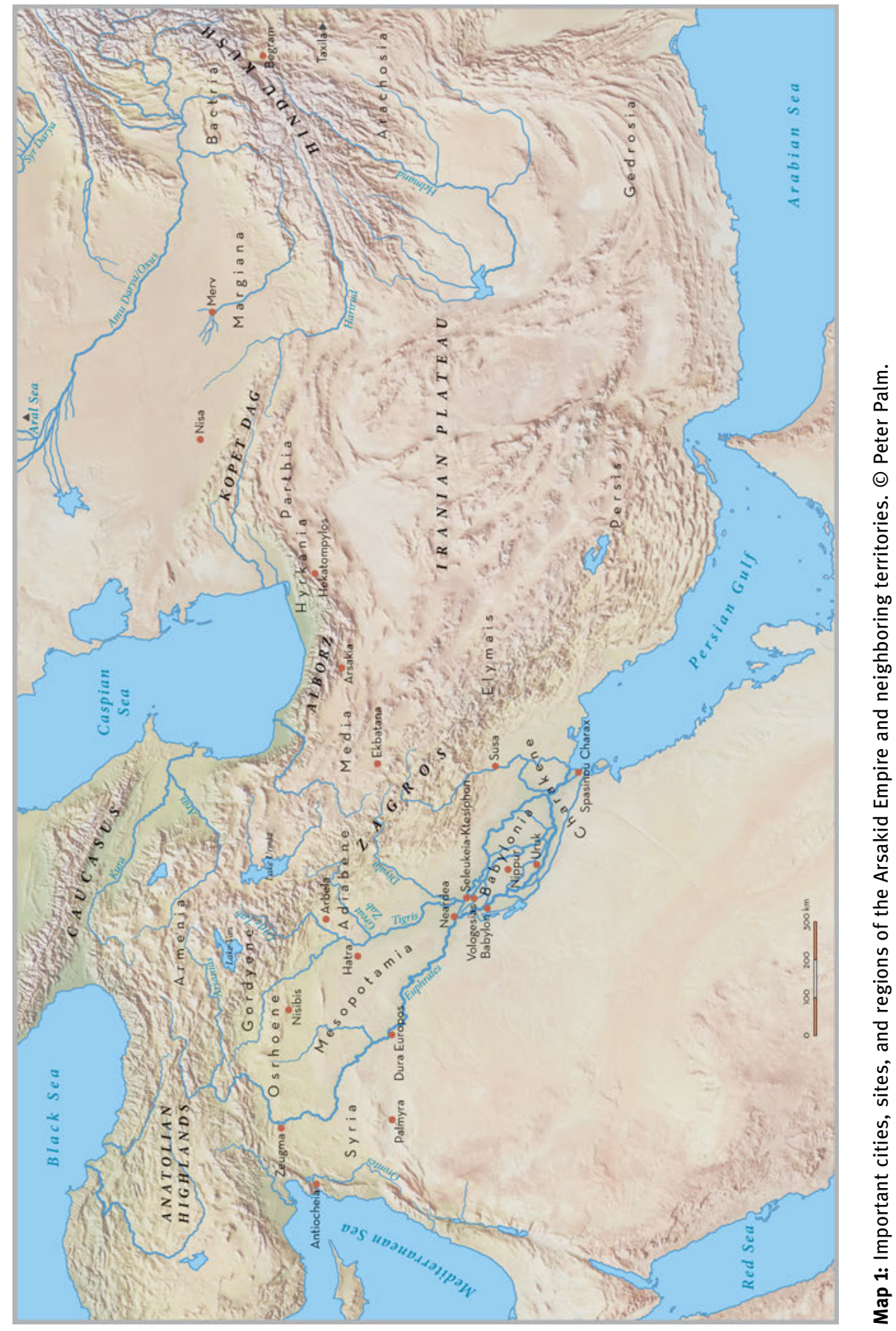


Empire into studies of antiquity also reflects historiographic biases. The Parthians "the stepchildren of ancient history" 5 - have had a difficult time drawing the attention of either Near Eastern or classical historians, while among scholars of the Iranian world, the Arsakid period has often been viewed as a transitional era between the more interesting Achaemenid and Sasanian periods. ${ }^{6}$

\section{I.1 The Space of the Empire}

Arsakid control developed across a range of challenging landscapes. At its greatest extent, it included territories (directly and indirectly ruled) from the edge of Anatolia to northern India, and from the Persian Gulf and Indian Ocean in the south to the Caspian Sea in the north (map 1$).^{7}$

The original heartland of the Arsakid dynasts - the Achaemenid satrapy of Parthava - was in northeastern Iran, within the area of Iran's contemporary Khorāsān provinces, as well as the Transcaspian steppe of southern Turkmenistan. Marked by the Kopet Dag mountains running east-west, and the Karakum and Kavir deserts to the north and south, the fertile area had seen many centuries of interaction between sedentary populations and mobile pastoralist (nomadic) groups. Moreover, the socalled Great Khorāsān Road, a corridor connecting India and Inner Asia to the center of Iran, Mesopotamia and points west, ran through the southern reaches of the territory.

Eventually, Arsakid power spread into Persis and the core of the Iranian Plateau, which had earlier been the seat of the Achaemenid Empire, as well as into the rich agricultural lands of Mesopotamia and its Tigris and Euphrates Rivers. The Arsakids consolidated control along the southern fringe of the Caspian basin, from the temperate Hyrkanian forests and the Alborz Mountains to the edges of the Greater Caucasus Mountains in the northwest, reaching down into the Armenian highlands. Finally, the empire came to include strongholds along the lower Euphrates and coastal territories along the northern edge of the Persian Gulf, stretched in some periods perhaps as far as Arachosia and northern India, although the eastern reaches of the empire are a point of uncertainty. ${ }^{8}$

\section{I.2 Arsakid Contexts: Dualities and Dichotomies}

The relative invisibility of the Arsakid Empire in modern thought is in sharp contrast to its omnipresence in Roman historical narrative, where Arsakid kings were a cen-

5 De Jong 2013a, 144.

6 Hauser 2012, 1001-1002; see also Wiserhöfer, ch. 11.I, this volume.

7 Bivar 1983, 24-27, for a description of Arsakid geography. For the physical geography of the territories of modern Iran, see Fisher 1968.

8 Frye 2004. 
tral foil for centuries. ${ }^{9}$ Despite its visibility, however, the nature of the Arsakid Empire on both a practical and conceptual level was only sketchily outlined by Roman authors, who struggled to fit unfamiliar Parthian practices into their own cultural vocabulary and stumbled over underlying differences in their imperial logics.

The Arsakid Empire can be said to be the second Iranian Empire, in a sequence that began with the Achaemenids and would continue in the Sasanians. Applying this same idea to cultural logics, however, is more problematic. Because of interaction (and intermarriage) between Seleukid and Iranian dynasties, Parthian elites were both conversant with and comfortable within the Greek-infused Hellenistic world, and were a particular vehicle for the spread of 'Hellenistic' sensibilities. ${ }^{10}$ Indeed, one of the recurrent themes of royal presentation among the Arsakids was an appeal to both Achaemenid and Macedonian (that is, Greek) sources in establishing legitimacy. ${ }^{11}$ Furthermore, the history of Arsakid Iran was also entangled with the world of steppe communities along the northern borders. ${ }^{12}$

In an attempt to grapple with these complex heritages, the Arsakid Empire is often simplified into a series of polarized dichotomies. ${ }^{13}$ The development of the empire is framed as a contest between 'Iranian' and 'Hellenic' influences within the Parthian court, while the underlying structural character of the court, the elite, and the army are considered alternately either fundamentally nomadic, or instead sedentary. These issues have been expressed as a set of questions: Did the structure of the Parthian aristocracy emerge from traditional steppe practices, or was it the product of Achaemenid or Hellenistic political systems? Was the Achaemenid Empire the source of Arsakid royal legitimacy, placing the Arsakids within an Iranian continuum, or was it instead the Hellenistic oikoumene from which they drew their power, making them somehow more Greek? In reality, the Arsakid Empire developed in the context of Iranian, Mesopotamian, Central Asian, Mesopotamian, and South Asian traditions. What characterizes the Arsakid Empire, more than any singular notional identity, was its ability to incorporate and accommodate a tremendously wide variety of administrative, structural, and iconographic frameworks as it grew. ${ }^{14}$

9 Lerouge 2007, 11. The importance of Parthians in Roman art and literature has led to a long tradition of studying Mediterranean representations of the Arsakid Empire. For recent contributions, see Landskron 2005; Lerouge 2007; Rose 2005; Wiesehöfer and Müller 2017.

10 Although the Hellenistic, and particularly the Seleukid, kingdoms were themselves borne from the fusion of practices from Greece (carried through Macedonia) with perspectives passed down in the long afterlife of Neo-Babylonian and post-Achaemenid forms of organization and administration (Fowler 2017, n. 29).

11 Shayegan 2011; 2017, 433-436.

12 The question of the depth of Parthian entanglements with pastoralist communities has been a subject of considerable debate. See below, sec. III.1.2 below for an overview of perspectives.

13 On polarization in the scholarship, see Fowler 2005, 129. On the inadequacy of these models with respect to ancient Iran, see Shayegan 2017, 401-403.

14 Keall 1994; Gregoratti 2017a discuss 'flexibility' as a trope of the Arsakid state. 


\section{The Rise and Transformation of the Empire}

\section{II.1 Origins and Origin Stories}

The story of the Arsakid Empire began in the confusing period surrounding the Seleukid Empire's loss of two significant satrapies in Central Asia - Parthia and Bactria. ${ }^{15}$ Although the details are unclear, both secessions appear to have been led by the respective satrapal governors: Diodotos in Bactria and Andragoras in Parthia. ${ }^{16}$ Andragoras's autonomous rule in Parthia was short-lived, as he was soon defeated by Arsakes and his supporters, with the year 247 BCE designated as the starting point of the Arsakid dynasty. ${ }^{17}$

The figure of Arsakes is mysterious and has been so since antiquity. In many of the ancient accounts, Arsakes was not himself a Parthian, but rather an outsider (often said to be from the steppe) who rose to power among the Parthians. ${ }^{18}$ The Roman geographer Strabo provides two such divergent stories about the founder and his followers. ${ }^{19}$ In the first and more elaborate, Arsakes is "a Scythian" who gains the support of the Parni (Aparni), a tribe that was part of the Dahae mobile pastoralist federation, and together with them moves southward into Parthia, conquering it. ${ }^{20}$ In the second version, Arsakes is reportedly "a Bactrian," pushed out by Diodotos and his expansionary desires, who turns his eye to Parthia. ${ }^{21}$ In Justin's third-century CE epitome of Pompeius Trogus, Arsakes is either a man from an unknown background who leads a group of brigands ${ }^{22}$ or a descendent of Andragoras himself. ${ }^{23}$ Finally, there is yet another tradition of Arsakes as a direct descendent of Artaxerxes, the Achaemenid king. ${ }^{24}$ It is difficult to make a cohesive whole out of these conflicting stories, and Hauser suggests that they should be seen, instead, as

15 On the entwined histories of the Arsakid and Bactrian territories, see Lerner 1999. See also Morris, ch. 2, this volume.

16 The chronologies of this period are debated. For an overview of alternate versions of early Arsakid history, see that provided in Bivar 1983, 28-31. For a fuller consideration of the literary sources for this period, see Wolski 1993, 37-51.

17 Wolski and others following him suggest that Arsakes did not actually come to power until 238, and that the date of 247 reflects the beginning of Andragoras's independent rule (Bivar 1983, 29).

18 De Jong 2013b, 30 makes a case for a Parthian ancestry for the Arsakids based on Zoroastrian religion.

19 Strabo 11. 9. 2-3.

20 Strabo 11. 9. 2. As Boyce has pointed out, this tradition of nomadic roots has found favor among contemporary historians. Although she argues against a nomadic character for all of Parthian culture, she does note that the ancient accounts of nomadic roots have "some slight support from what appears to be a genuine Parthian tradition preserved in a Middle Persian text” (1994, 242).

21 Strabo 11. 9. 3.

22 Justinus Epitome of Pompeius Trogus (Just. Epit.) 41. 4. 6-8.

23 Just. Epit. 12. 4 . 2.

24 Arrian Parthica frag. 2. The clearest version of this story comes through Syncellus, a Byzantine author quoting Arrian. Lerouge 2007, 187-192 discusses Arrian’s treatment of Arsakes. 
literary accounts that "employ the typical rhetorical figures and topoi of foundation myths."25

The uncertainties surrounding the early years of the Arsakid dynasty extend beyond the identity of Arsakes. As Strootman has pointed out, there is good reason to question accounts of the rise of the Arsakid dynasty that treat it in "the model of the sovereign nation state" and posit a quick crystallization of a self-conscious empire. ${ }^{26}$ These perceptions simplify the entwined networks of power and kingship that ran through Seleukid and later Arsakid Iran and Central Asia, from which the Parthians emerged and within which they continued to function.

In any case, according to the traditional account, Arsakes was joined in his aggression by his brother, Tiridates, who became king after the death of Arsakes I. More recently, and following the hypothesis of Wolski, many now argue that Tiridates may not have existed, and that the Arsakid throne passed from father (Arsakes I) to son (Arsakes II) around 217 вCE. ${ }^{27}$ Numismatic evidence seems to support this conclusion, although the Arsakid dynastic habit of using the throne-name 'Arsakes' for each monarch complicates matters, and there is not complete agreement. ${ }^{28}$

Iran was, at this point, a space of divided power, with Arsakid, Bactrian, and Seleukid interests vying for control. Although little can be said with certainty about these early decades, textual evidence suggests Arsakid spatial reorganizations, with the creation of new settlements and fortification of old ones. ${ }^{29}$ The early Arsakid dynasts managed to repel the most serious threats to their growing state, with Arsakes II (r. ca. 217 BCE-ca. 191 BCE) offering largely statutory submission to the Seleukid monarch Antiochos III. ${ }^{30}$ Little is known about Arsakid history for several subsequent decades, save some sparse information that Phraates I (r. ca. 176-171) conquered territories around the Caspian's southern shores, marking the earliest steps of the coming period of Arsakid expansion.

\section{II.2 Becoming an Empire}

Mithradates I (r. ca. 171-132 BCE) presided over the rise of the Arsakid state as a significant power. He capitalized on the diminishing cohesion of the Seleukid Empire in the mid-second century всE, expanding Arsakid control deep into Seleukid territory in Media, Babylonia, and Elymais (all conquered between 148 and

25 Hauser 2012, 1003. A fuller discussion of this can be found in Hauser 2005.

26 Strootman 2017, 184.

27 Wolski 1946, 160.

28 Strabo 15. 1. 36. Bivar 1983, 30-31 for example argues for the traditional version of succession transmitted by the classical authors. See also de Jong 2013b, 30.

29 Just. Epit. 41. 5. 1-3.

30 Dąbrowa 2012, 169. 
138 BCE). ${ }^{31}$ Although Mithradates I had widespread success, the victories did not come easily, and Arsakid hold on its new territories was fiercely contested. ${ }^{32}$

Mithradates I's successors, Phraates II (r. 132-126 BCE), Artabanos I (r. 126-123/ 2 BCE) presided over a confusing period of conflict with new and old enemies in both the east and west. The period saw the westward shift of the Arsakid center-ofbalance, from its original core in eastern Iran, toward the denser and more profitable territories of Media and eventually Mesopotamia. ${ }^{33}$ This shift was embodied in the physical transfer of the capital city from its early location at Nisa (mod. Turkmenistan) to Ekbatana (mod. Hamadān, Iran) and then finally to Ktesiphon, near the old Seleukid capital at Seleukeia-Tigris (mod. Baghdad, Iraq). ${ }^{34}$ The imperial recentering coincided with a new set of pressures on the eastern flank of the Arsakid Empire as the Yuezhi mobile pastoralist confederation took control of Bactria. The Yuezhi came into the picture as part of a larger phase of migrations and resettlements precipitated by upheavals farther to the east. ${ }^{35}$ Beyond the Yuezhi, Phraates II found himself facing Seleukid attempts to retake parts of their lost lands in Media and Mesopotamia, as well as incursions from the east by another mobile pastoralist group, the Saka, who proved to be a nagging threat for the next several generations. ${ }^{36}$ In the end, the Seleukid efforts were unsuccessful, and the eastern frontier was stabilized, although these distractions created an opening for the defection of Charakene in the south.

Under Mithradates II (r. 122-91 BCE), the Arsakid Empire entered a period of territorial reclamation and renewed growth. Mithradates retook lost territories in Mesopotamia and Iran, as well as in Central Asia, where it appears that Parthian vassals came to power and became durable allies, although little is known about them. ${ }^{37}$ Mithradates also spread Arsakid interests into Armenia and Anatolia, waging war against Armenia ${ }^{38}$ and likely bringing the rulers in Adiabene, Sophene, Gordyene, and Osrhoene into the Arsakid fold. ${ }^{39}$ By the end of his reign, Arsakid

31 Cuneiform texts have been particularly helpful in clarifying the chronology of Arsakid activities in Mesopotamia in the middle of the second century BCE. Shayegan 2011, 60-120 discusses relevant evidence.

32 See for example the battles between Mithridates I and Demetrios II of Syria, who fought to regain Mesopotamia in 139/138 ВСE, as well as the fierce engagements with the kings of Elymais and Charakene. On Elymais, see Dąbrowa 2014; Potts 1999, 384-391; 2002. On Charakene, see Schuol 2000.

33 Hauser 2012, 1004.

34 Bivar and others have hypothesized that the movement away from Nisa was incited by the vulnerability of the original Arsakid heartland to nomadic raids from the north $(1983,39)$.

35 Morris, ch. 2, this volume.

36 Conflicts with the Saka claimed the lives of not only Phraates II, but also Artabanos I.

37 Frye 2004 discusses this eastern space. See also Morris, ch. 2; Dwivedi, ch. 3, this volume.

38 Strabo 11. 14. 15.

39 The dating of these events is uncertain, and it is possible that some of the territories already were incorporated under Mithradates I. On Adiabene, Sophene, and Gordyene, see Marciak 2017, 128-129, 244, 346-347. 
territory stretched from Dura Europos along the Euphrates in the west to Margiana in the east, and from Hyrkania in the north to Charakene in the south. The developments under Mithradates II were not just territorial, but also cultural. The seat of the empire was securely established in the urbanized context of Seleukeia-Tigris and the manner of Arsakid dynastic titulature changed, including the earliest attestations of the archaizing title 'King of Kings,' (see below).

\section{II.3 Encounters with Rome}

The first recorded diplomatic encounter between the Arsakid and Roman Empires occurred in the mid-90s BCE, when an emissary of Mithradates II met with the Roman governor of Kilikia, Sulla, to propose the establishment of the Euphrates as the border between the Roman and Arsakid spheres of interest. ${ }^{40}$ Despite Mithradates II's attempts, the early decades of the first century BCE were not marked by continued Arsakid expansion or greater political prominence. Instead, the rise in ca. 92 BCE of a powerful rival for the Arsakid throne, Gotarzes, began a period of internal turmoil in the last years of Mithradates II's rule, which only intensified in the struggle over succession after his death. ${ }^{41}$ He was succeeded by Sinatrukes, thought to be a son of Mithradates I, rather than one of his own sons. In the aftermath of this, two lines claiming royal legitimacy rose: the Sinatrukids and the so-called Younger Arsakids, descended from Mithradates II. ${ }^{42}$

During these years, the Roman commanders in the east were occupied by their conflict with Mithridates IV Eupator, the king of Pontos. Tigranes II of Armenia, an Arsakid vassal, used the general unrest to expand his purview, offering extensive support to Mithridates IV in his fight against the Romans. A succession of Arsakid kings (first Sinatrukes and then Phraates III), in contrast, maintained neutrality in the conflict between Pontos and Rome. In exchange for this neutrality, and to encourage its continuation, several Roman generals (first Lucullus and then Pompey) offered their endorsements of the Euphrates as the dividing line between Roman and Arsakid interests. ${ }^{43}$ From the perspective of the Arsakid Empire, these efforts at stabilization were largely ineffective. The dynastic strife inside of the Arsakid world continued apace after the assassination of Phraates III by his two sons, Orodes II and Mithradates III, in 58/7 BCE.

40 Plutarch Life of Sulla (Plu. Sull.) 5. 4-5. The interaction was not without problems: Mithradates II reportedly executed his emissary after hearing that he allowed Sulla to denigrate the power of the Arsakid crown by equating the Arsakid king with a minor (Pontic) king.

41 On the complexities of this period and the role of numismatic data, see Mørkholm 1980; Bivar 1983, 41-45. Assar 2009; Simonetta 2009 discuss ongoing revisions of the chronology based on numismatics.

42 Olbrycht 2016a.

43 Bivar 1983, 45-47. 
This instability eventually drew the attention of Roman authorities, who likely saw an opportunity to expand Rome's holdings in the Near East. Mithradates III provided the proximate cause for Roman intervention, after he requested Roman aid in his conflict against his brother. ${ }^{44}$ Mithradates's request led to the campaign of the Roman general M. Licinius Crassus, who broke the decades-old Euphrates truce as he marched against Orodes II. These were the first open hostilities between the Arsakid and Roman armies. By the time Crassus made it across the Euphrates and past pro-Arsakid territories in Osrhoene, however, Mithradates III had been defeated. Crassus nevertheless attacked, suffering a shattering defeat of the Roman forces at Carrhae in 53 BCE, at the hands of the army of the pro-Orodes Parthian nobleman Suren, described by the ancient biographer Plutarch as first after the king. ${ }^{45}$

In the century following Carrhae, our knowledge of the affairs of the Arsakid Empire suggests considerable dynastic strife, as well as ongoing hostilities between Rome and the Arsakid Empire. The early years of Orodes's reign were spent stabilizing his position. He executed his victorious general Suren, undoubtedly to limit the ambitions of the powerful clan, ${ }^{46}$ and turned his attention to resecuring Armenia, whose king Artavasdes II had entered into an alliance with Crassus. Successful in this endeavor, Orodes sealed the alliance with Artavasdes through a dynastic marriage between an Arsakid prince and Armenian princess, ${ }^{47}$ beginning a centurieslong dynastic relationship between the houses. ${ }^{48}$ Orodes took advantage of his surprising victory as well as unrest precipitated by the Roman civil war between Caesar and Pompey to launch several campaigns into Roman territories in the Near East, first in 51 BCE and then again in 41 BCE. Although Arsakid troops did not intervene in the fighting between Caesar and Pompey, they were on the side of Pompey, ${ }^{49}$ and continued to support his faction after the assassination of Caesar. ${ }^{50}$ In the second Arsakid incursion into Roman territory in 41 BCE, the Arsakid forces were led by Orodes's son Pakoros, as well as by Q. Labienus, a Roman general and supporter of the Republican cause. The two led a temporarily successful invasion of Syria and Judaea, bringing nearly all of the Near East into Arsakid hands. ${ }^{51}$ The Arsakid victory was short-lived though, as both Labienus and Pakoros were killed by Antony's forces, plunging the Arsakid monarchy into renewed dynastic struggle.

\footnotetext{
44 Cassius Dio (Cass. Dio) 39. 56. 2.

45 Plutarch Life of Crassus (Plut. Crass.) 21. 6.

46 Olbrycht 2016a, 23.

47 Plut. Crass. 33. 1.

48 Bivar 1983, 56; Dąbrowa 2018, 80.

49 Supporting, for example, the Pompeian general Q. Caecilius Bassus, who had been cornered by Caesarian forces at Apameia after the death of Pompey.

50 Bivar 1983, 56-57.

51 Schlude and Overman 2017 on the situation in Judaea, interesting because of the ties between Jewish populations under Arsakid rule in Babylonia and those in Judaea.
} 
Orodes II stepped down, passing the throne on to his son Phraates IV (r. 38-3/ 2 вCE). But Phraates did not have universal support from the noble families, many of whom fled to Roman territory and launched (Roman-supported) opposition. In this climate of fractured alliances, Marc Antony began to plan a massive invasion of Media in 36 BCE with the help of, among others, the Armenian king Artavasdes II. Following the defection of Artavasdes and a successful attack on the Roman troops by Arsakid forces under the command of Phraates, however, Antony was forced to retreat. This episode began yet another wave of jockeying for authority in Armenia, which ended with the installation of the pro-Arsakid Artaxes II, son of Artavasdes II. Internal strife in the Arsakid sphere continued. Phraates IV was forced to turn to the so-called Scythian allies to hold on to his throne in the face of opposition from a certain Tiridates, who would eventually flee to Roman territories, but not before abducting Phraates's son, whom he handed over as a hostage to Rome.

The situation between the Roman and Arsakid Empires entered a new phase with the rise of Augustus, who in 20 BCE initiated a diplomatic settlement to the strife in the Near East, which resulted in the return of the Roman military standards and prisoners captured at Carrhae. The moment offered Augustus a tremendous public relations coup: a nearly free and bloodless victory with tangible symbolic ramifications. Although the largely symbolic concessions likely did not cause practical problems for Arsakid rule, Phraates's willingness to bow to Roman demands was seen by his internal opponents as a sign of weakness. ${ }^{52}$ The Armenian noble families, seeing an opening to rid themselves of the Arsakid-supported Artaxes II, murdered him and initiated a new period of Roman-Arsakid feuding in Armenia. These tensions continued until 1 CE, when the son of Phraates IV, Phraatakes (r. 3/ 2 BCE-2 CE) yielded hegemony in Armenia to the Romans. Phraatakes was an unsuccessful king, thought to have been largely the puppet of his mother Musa, an Italic slave who had been given as a gift to Phraates IV by Augustus as part of the peace settlement. ${ }^{53}$ In short order, he was forced out of power by Arsakid aristocrats in 4 CE. For nearly a decade, Arsakid aristocrats and Roman interests vied to impose their chosen candidate on the Arsakid throne.

Eventually, Artabanos II (r. 12-38/9 CE), a member of the Younger Arsakid line who had been ruling in Atropatene and who was likely descended from Mithradates II, came to the throne. This marked the end of the Sinatrukid line on the main Arsakid throne, although a branch of that line is thought to have split off and begun the dynasty of Gondophares ruling in eastern Iran and Northern India, with the support of other Parthian noble houses. ${ }^{54}$ Artabanos, recognizing the danger posed by the strong Arsakid nobility of recent generations, began to take more direct con-

52 Bivar 1983, 66-67; Dąbrowa 2012, 173.

53 Strugnell 2008.

54 Bivar 2007; Olbrycht 2016a, 24. 
trol over Arsakid territories and curry favor among powerful minorities within the empire as a way of diluting the power of the traditional ruling families. ${ }^{55}$

Despite an early attempt to reassert Arsakid influence in Armenia, Artabanos largely accepted the state of affairs. However, following a failed attempt in $35 \mathrm{CE}$ to place his son on the Armenian throne, Artabanos faced opposition from Romebacked nobility, and was forced to find support from eastern 'nomadic' elements of the Arsakid community, retaking kingship at the head of an army of Saka and Dahae. ${ }^{56}$ Another decade-long period of instability followed his death, once again featuring internecine fighting, as well as the continued prominence of the Dahae and Hyrkanians, who supported Gotarzes, one of the sons of Artabanos II.

\section{II.4 Arsakid Stabilization and Transformation}

The rise of Vologases I (r. ca. 51-78/9 CE) marked the beginning of a period of stability and imperial innovation that continued during the rule of his son Pakoros II (r. ca. 77/78-110 CE). ${ }^{57}$ One critical element of this stability was the articulation of a lasting solution to the question of Armenia, which came after the Arsakid victory at the battle of Rhandeia in $62 \mathrm{CE}$. The lead-up to this battle began when the Romanbacked Caucasian Iberians seized the Armenian throne, a move that Vologases rejected as a breach of the previous Roman-Arsakid agreement. In response, he placed his brother, Tiridates, on the throne, sparking the military campaign of Gn. Domitius Corbulo. Corbulo achieved considerable success in his invasion of Armenia, forcing Tiridates out and briefly installing Rome's choice on the throne. However, the Arsakid army was eventually able to out-fight Corbulo's replacement, leading to a victory at Rhandeia that cemented the new state of Armenian affairs: the Arsakid king would appoint his choice for the Armenian crown, who would then be crowned by the Roman emperor. In practice, then, authority over Armenia had transferred to the Arsakid emperor.

This stabilization of the long-contentious Caucasus, interrupted only by an apparent invasion of mobile pastoralists from the North Caucasus in $72 \mathrm{CE},{ }^{58}$ allowed Vologases to turn his sights toward retaking Arsakid territories from Mesopotamia through Elymais, ${ }^{59}$ as well as expanding Arsakid interests farther to the east, through Choresmia and Bactria, in a program continued by Pakoros. Dynastic strife arose again late in the reign of Pakoros II, who was at the time co-regent with his son, Vologases III (r. ca. 110-147), and led to the domination of much of Arsakid

55 Gregoratti 2014, 52-53.

56 Gregoratti 2013, 47-48.

57 For a recent reassessment of this period on numismatic grounds, Olbrycht 2016c.

58 On these mobile pastoralist incursions, see Bosworth 1977.

59 The nature of relations between Elymais and the Arsakid Empire in this period is uncertain, Dąbrowa 2014. 
territory in Mesopotamia by a usurper, Osroes I. Osroes incited Roman involvement in Armenia by crowning Parthamasiris as the king of Armenia without Roman involvement, creating the pretext for Trajan's invasion of Armenia and the Arsakid heartland in Mesopotamia. Roman forces scored significant victories, capturing Ktesiphon for a period, and making their way all the way to the Persian Gulf. But the Roman grip on the territories was short-lived, and entirely abandoned under the Roman emperor Hadrian (r. 117-134). However, the years of unrest had changed the balance of power in the Arsakid realm and seem to have resulted in a split empire, with Osroes controlling the western reaches and Vologases III ruling in the east. By 128/9, Vologases III seems to have reunited the kingdom. ${ }^{60}$

Pressures on the Arsakid Empire from mobile pastoralist neighbors mounted in this period. In $135 \mathrm{CE}$, they faced a renewed invasion from the North Caucasus, once again involving the rulers of Iberia. ${ }^{61}$ At the same time, the Kushans in the east were growing rapidly, forcing a reallocation of Arsakid attention and resources. Tensions with Rome flared again under Vologases IV (r. 147-191/2), who was successful in regaining Arsakid supremacy in Charakene early in his rule. With this victory, he reasserted an important income stream for the Arsakid throne in the form of taxes collected on goods moving through the port territory on the Persian Gulf. But in $161 \mathrm{CE}$, he launched an ultimately unsuccessful campaign into Roman territory, which turned into a victory for Roman forces. This episode led to the definitive loss of Arsakid holdings in Syria, which would never be regained, as well as shifts in control over other parts of northern Mesopotamia.

A renewed Roman campaign into Arsakid lands commenced under the Roman emperor Septimius Severus (r. 193-211), who invaded the Arsakid realm in 197/8 CE. This event had considerable success in expanding Roman control in the territory, despite Severus's failure to capture Mesopotamia proper. The final Roman offensive against the Arsakid Empire commenced under the emperor Caracalla, who took advantage of internal strife between feuding throne claimant brothers. The campaign did not yield any meaningful Roman victories and ended with the assassination of Caracalla in 217, which was followed by opportunistic incursions of Roman

60 For disagreement on this point, contrast the positions of Dąbrowa 2012, 176 with that of Bivar 1983, 93.

61 Cass. Dio 69. 15. 1-3. On these raids, see Bosworth 1977; Perevalov 2006. On the broader question of interactions between these northern pastoralist groups and the Parthians, see particularly Kharmatta 1965. 
territory by the Arsakid army, and a peace settlement including a significant financial payoff by Caracalla's successor. This peace settlement is the last known episode of Roman-Arsakid interaction. Shortly thereafter, an uprising led by Ardašir, the ruler of Persis from a noble family, took hold and spread into Media and Adiabene. From this base, the insurgents were able to overtake Artabanos IV in his seat at Ktesiphon, killing him and claiming both the capital city and the title of 'King of Kings' for Ardašir, inaugurating the Sasanian dynasty who would rule Iran for the next four centuries.

\section{The Shape of Arsakid Rule: The Logics of Arsakid Control}

The Arsakid Empire is marked by its decentralized and multipolar structure, and in this sense has the character of a hierarchal confederation. The course of events within the empire was shaped by tensions between its various internal centers, as well as by the separatist tendencies of its vassal territories and the creation of new power bases like the one that arose in the empire's eastern Indo-Parthian fringe. Although these centrifugal tensions have often been interpreted as indications of imperial weakness, the system forced Arsakid dynasts to rule with flexibility. ${ }^{62}$ Arsakid control was based on a balance between the elements of their system, enacted across the sprawling networks that connected the empire. Three elements of imperial practice are of particular importance in understanding how power flowed across these networks. They are: (1) the image of kingship that emanated from the King of Kings himself, shaping his relationship with the Parthian aristocracy, as well as dependent kings; (2) the coercive power of the Arsakid army that enabled their territorial expansion, as well as the diplomatic ties that emerged in its wake; and (3) the techniques for control of space, which enabled the Arsakid dynasty to shape interaction across their empire.

\section{III.1 Socio-Political Contexts of Arsakid Rule}

At the center of the Arsakid system was a king who enjoyed a form of absolute power, who was invariably a descendent of the founder of the dynasty (or at least, was presented as such), ${ }^{63}$ and who benefited from some sort of ruler cult. ${ }^{64}$ The

62 On the 'weak king' trope, see Hauser 2006, 296. See also Fowler 2010, 57-59 on the notion of 'petty kings' in the Arabic and Persian historical traditions.

63 Strabo 16. 1. 28.

64 On the existence of a ruler cult, Dąbrowa 2009, 2011. 
king was surrounded by a small group of elite families drawn at first from the ranks of the Parthians, which expanded to incorporate local elites in conquered territories as the empire grew. ${ }^{65}$ The socio-political practices of this elite sector of society became increasingly visible in neighboring territories, creating a recognizable elite cultural koine. ${ }^{66}$

\section{III.1.1 Arsakid Kingship: Coin Portraits and Palaces}

The history of the Arsakid dynasty is marked by frequent conflict between different branches of the ruling family and their elite Parthian kinsmen. In this fractious environment, claims of authority and legitimacy by Arsakid kings were critically important. Recombining elements drawn from Achaemenid, Hellenistic, and steppe models, successive generations developed a vision of authority that responded to both internal and external tensions. ${ }^{67}$ That is - the version of kingship that developed within the Arsakid space was neither an incomplete copy of Seleukid approaches, nor a distant recreation of Achaemenid ones, but instead a new practice rooted in the conditions of the Parthian period.

Since we lack synthetic accounts of the Arsakid ideology of rule, central evidence for considering the institution of kingship comes from court art. ${ }^{68}$ Within this body of material, coin portraits offer widespread and diachronic glimpses at imperial representation, while court architecture provides a window into a more private form of imperial representation. ${ }^{69}$

The Arsakid monetary system was bimetallic, with two silver denominations, tetradrachms and drachms, as well as bronzes. ${ }^{70}$ Many coins were issued with mint marks, and a number of the mints have been identified in both Mesopotamia and Iran. The local nature of minting practices in various corners of the Arsakid world

65 Dąbrowa 2013, 54, n. 4 cites Himerus, a Hyrkanian elite who became the satrap of Mesopotamia under Phraates II. For prosopographical data on the aristocratic families, see Karras-Klapproth 1988. Among these elite families, one can add the western Arsakids, the Gondopharids, and the Sūren and Kāren (Olbrycht 2016a, 31).

66 De Jong 2013a.

67 Canepa 2017.

68 On the differences between Arsakid court art and Parthian art, Invernizzi 2011. Many debates about Parthian art more generally can be traced back to Rostovtseff's analysis of the art of Dura, which argues that Parthian art represents an Iranian rejection of Hellenic models (Rostovtzeff 1935), see Dirven 2016 for a summary of debates. For other important discussions, see Ghirshman 1962; Schlumberger 1970.

69 A number of rock reliefs preserve images of Arsakid kings. They appear to be the product of local commission rather than of the Arsakid court itself (Invernizzi 2011, 194), and therefore present indirect evidence about Arsakid dynastic art. On the reliefs, Kawami 1987; Mathiesen 1992.

70 Vardanyan 2001, on the monetary system. Drachms were the most widespread of the denominations. 

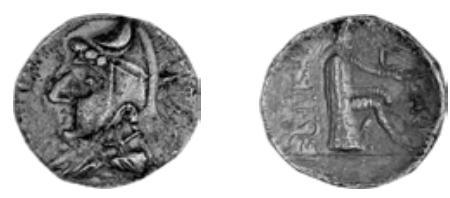

Fig 1: Silver drachm of Parthia, early king, late third/early second century BCE, obv. Head of the king wearing bashlyk, facing left. Rev. Seated archer, right. Diameter $19 \mathrm{~mm}, 3.46$ g., $12 \mathrm{~h}$., Sellwood 4.1. ANS 1944.100.81998. (c) American Numismatic Society.

seems to reflect the decentralized and heterogenous nature of imperial power. The coins generally offer at least one royal portrait, as well as a variety of epigraphic clues about royal titles, packaged as imperially sanctioned royal propaganda. ${ }^{71}$

The earliest Arsakid coins are from the time of Arsakes I and his successors (fig. 1). ${ }^{72}$ These have been seen to demonstrate close affinity to coins of the postAchaemenid fratarak $\bar{a}$ rulers in Persis. ${ }^{73}$ The iconographic language, which includes a left-facing, clean-shaven monarch wearing a pointed tiara, is seen as a divergence from (and perhaps even an active rejection of) Seleukid numismatic vocabulary. ${ }^{74}$ Some early coins of Arsakes I feature the title $\langle\mathrm{krny}\rangle$, interpreted by some as the Middle Iranian term kären in Aramaic script, which appears to be a reanimation of an Achaemenid title - providing early evidence for self-conscious Arsakid recollections of the Achaemenid Empire. ${ }^{75}$ Nevertheless, a divergent reading of the iconographic program of early Arsakid coins suggests a greater interaction with Seleukid idioms - and even posits western Asian roots for some of the characteristic elements - suggesting that it is also possible to read the coins within their most proximate Seleukid imperial context. ${ }^{76}$

Mithradates I at first continued the precedents of his predecessors, ${ }^{77}$ but then adopted a number of Seleukid characteristics on his coins. ${ }^{78}$ On the obverse of these types, the king faces right in Seleukid style, wears a Seleukid diadem and an outfit

71 Sellwood 1980 is the standard reference, and more recently the ongoing work of the Sylloge Nummorum Parthicorum. Examinations of Arsakid coins have a long history within studies of the chronology of Arsakid kingship both in the empire and in vassal states, for example Le Rider 1965; Loginov and Nikitin 1996; Alram 1998; Simonetta 2001; Assar 2006b, $2006 a$.

72 Sellwood 1980, types 1-6.

73 On the fratarakā coinage, Wiesehöfer 2011.

74 Vardanyan 2000; Sinisi 2014. The most visible example of this is the direction of the portrait. Seleukid convention used a right-facing portrait, but the early Arsakid issues flip this to left-facing. 75 Sellwood 1980, type 3.1-2, 4. See Olbrycht 2013, 65-68; Shayegan 2017 for a discussion of this issue. On the term kara-na-, see Shayegan 2011, 170-176; Hyland 2013.

76 Strootman 2017, 187-192.

77 Sellwood 1980, types 7-10.

78 Thus, the use of a diadem rather than a tiara (Sellwood 1980, type 11), the presence of the omphalos instead of a throne, and the flipped direction of the portrait (Sellwood 1980, type 12-13). See Sinisi 2014. 

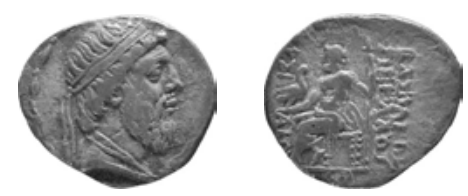

Fig 2: Silver drachm of Mithridates I, 171-138 BCE, from Seleukeia-Tigris, obv. Head of king wearing a diadem, facing right. Rev. Zeus seated, left, holding eagle. Diameter $20 \mathrm{~mm}, 3.27 \mathrm{~g} ., 1 \mathrm{~h}$, Sellwood 13.6. ANS 1944.100.82046. (C) American Numismatic Society.

that evokes a chiton (fig. 2). But the images of Mithridates I's coinage are not purely a quote of Seleukid norms. The king is shown wearing a beard and a hairstyle that is not entirely Seleukid, and in a second image on the reverse, the figure sometimes wears not a chiton, but a trouser-suit, the Parthian costume. ${ }^{79}$ Mithradates I also began to use of the epithet philhellenos on coins minted at Seleukeia. ${ }^{80}$ The term reflects the king's self-presentation as friendly to his new Greek subjects, but at the same time, its use maintains his alterity, since to be 'Greek-loving' is to be explicitly not Greek. ${ }^{81}$ In Mithradates I's coinage, then, we see a response to newfound control of the former Seleukid capital and an adjustment of earlier practice amid changing conditions.

After Mithradates I, many of the more obvious Seleukid borrowings were abandoned, although the use of philhellenos continued. It is in this period that a new royal image emerged, ${ }^{82}$ clear in the costume of the dynasts from this point forward. From the domed tiara of Mithradates II to the combination of the diadem and hairstyle of Orodes II, this image was neither purely Achaemenid nor Seleukid. Next, the coinage of Mithradates II introduced the epithet: 'King of Kings.' This term, never used in the Seleukid court, is seen to indicate a growing Iranian revival among the Arsakid kings and Parthian elites beginning in the first century BCE. ${ }^{83}$

After this, the design of drachms became increasingly fixed, as well as stylized: an obverse featuring a left-facing portrait; a reverse with the image of an archer (e.g., ch. 11, fig. 3b and 3c). ${ }^{84}$ Despite the standardization, by the end of the first century BCE, Arsakid coin issues had begun to diverge into several stylistic schools. ${ }^{85}$ Although it is clear that the overall endeavor of minting was still centrally

79 Curtis 1998 for costume.

80 Wiesehöfer 1996; Dąbrowa 1998 for discussion and earlier bibliography on Arsakid royal epithets.

81 Fowler 2005, 152.

82 Fowler 2005, 147.

83 This is a debated point, Curtis 2007, 15 for the traditional view; Fowler 2005 for an alternative interpretation. On the coinage, Sinisi 2014, 14-15.

84 Sinisi 2014, 14.

85 Sinisi 2014, 23-25. 
planned, the stylistic variation of the later Arsakid coins reflects a pattern of pronounced regionalism that is familiar from other Arsakid contexts.

The coin portraits, then, provide glimpses of the changing Arsakid representations of power and authority, as well as shifting conditions within Arsakid space. Another body of evidence available for considering Arsakid royal ideology and selfpresentation in the first two centuries of the dynasty comes from excavations at Nisa in Turkmenistan, an imperial capital. An ostracon supports the identification of part of the site, Old Nisa, as Mithradatkert, founded by Mithradates I during the period of the Arsakid state's transformation into an imperial power. ${ }^{86}$ Nisa provides a rare window into the cultural context of the Arsakid emperors, showing how they chose to construct the physical seat of their empire.

The site has been excavated since the 1930s, including long-running campaigns in the Soviet period and more recent work by an Italian-Turkmen project. ${ }^{87}$ It is composed of two parts, a large fortified settlement area called New Nisa and the separately fortified area of Old Nisa. ${ }^{88}$ Invernizzi calls the layout of Old Nisa "paratactic" relating this conceptual configuration of space to Achaemenid palace complexes. ${ }^{89}$ He identifies a difference between the building plans, which he attributes typologically to Central Asian Iranian traditions, and building ornamentation, where Greek stylistic vocabularies are in use. ${ }^{90}$ An example of the melding of the two approaches comes from the Round Hall. The structure is thought to be a dynastic shrine, perhaps parallel to the Philippeion at Olympia. ${ }^{91}$ The building's architectural form is not dependent on Greek models though, and indeed the best parallels for the architectural forms of Old Nisa come from Ai Khanum, which similarly developed atop an Achaemenid substrate, layered with (among other things) Central Asian and Seleukid practices. ${ }^{92}$ But the sculptural program, particularly of the Round Hall, featuring monumental clay statues found in an unfortunately fragmentary state, reflects clear familiarity with sculptural forms of the Seleukid world (figs. 3 and 4). ${ }^{93}$ Furthermore, these pieces were sculpted in situ, and therefore reflect the physical presence of artisans likely trained elsewhere in the Hellenistic world at the Arsakid court. ${ }^{94}$ Additional evidence for the extent to which Arsakid court art was entangled with its Seleukid neighbors comes from marble statuettes,

86 Diakonoff and Livshits 1977, 1.2.1: 47, ostracon n. 478. On the debates over the location of Nisa, see Pilipko 1989. The site of Arsakes's earlier capital, known as Asaak (Astauene) is unknown.

87 Pilipko 2001. For the more recent work, see Invernizzi and Lippolis 2008.

88 Canepa 2018, 71-77; see also Invernizzi 2001; Pilipko 2001, 2008.

89 Invernizzi 1997, 112.

90 Invernizzi 2011, 198-199; 2016.

91 Invernizzi 2011, 199.

92 Hauser 2012, 1006-1007; Invernizzi 2016.

93 Although the large-scale terracottas also find affinities with other Central Asian architectural and sculptural practice. On these terracottas elsewhere, Pugachenkova 1971.

94 Bollati 2008. 


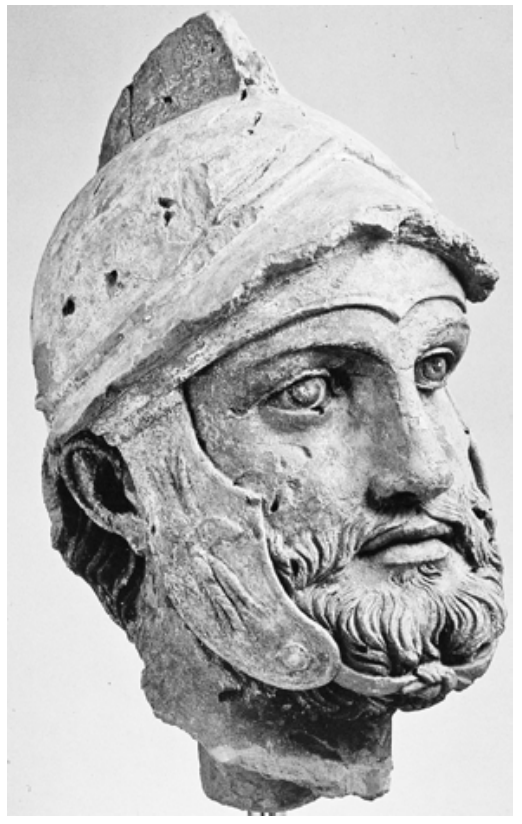

Fig. 3: Head of a warrior in clay, from the Square Hall at Nisa. (c) Centro Scavi Torino.

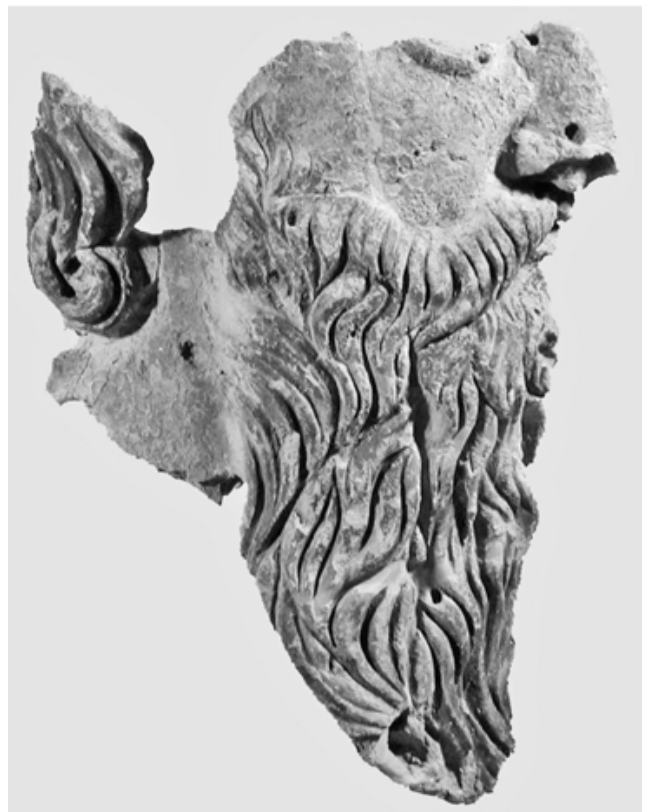

Fig. 4: Part of a clay sculpture, possibly Mithridates I, from the Round Hall at Nisa. (C) Centro Scavi Torino.

metal figurines, and a collection of around 40 ivory rhyta (conical drinking cups) bearing scenes from Greek mythology, all found at Old Nisa. ${ }^{95}$ These objects, often interpreted as imports, could well have been produced by craftsmen working in Central Asia, though ones with a deep familiarity with Seleukid stylistic currents.

In addition to Nisa, literary sources suggest Arsakid capitals and royal residences at a number of other cities, including Ekbatana, ${ }^{96}$ Rhagae, ${ }^{97}$ and Hekatompylos, ${ }^{98}$ as well as eventually Ktesiphon. ${ }^{99}$ Unfortunately, these later capitals have revealed neither Arsakid royal residences nor imperial architecture of the type known from Nisa, so we have a limited understanding of the development of Arsakid imperial architecture or sculptural programs. ${ }^{100}$ Across the sphere of Arsakid interaction, however, a number of other dynastic shrines may be identified, suggest-

95 On the rhyta, Masson and Pugacenkova 1982; Pappalardo 2010.

96 Strabo 16. 1. 16.

97 Athenaios Deipnosophistai 12. 513.

98 Strabo 11. 9. 1; Pliny the Elder Naturalis historia (Plin. HN) 6. 44.

99 Strabo 16. 1. 16; Tacitus Annales (Tac. Ann.) 6. 42. 6. Concerning the various Arsakid capitals and residences, see Chaumont 1973.

100 On the identification of Hekatompylos with Šahr-e Qūmes, near Dāmḡān in Iran, see Hansman and Stronach 1974; Hansman 1981. 
ing that an organized imperial cult became part of kingship among the Arsakids and their contemporaries that marked kingship as explicitly sacral. ${ }^{101}$ This vision of Arsakid kingship is confirmed in the report of the Roman historian Ammianus Marcellinus (ca. 330-395), who describes the deification of Arsakes I upon his death, and the subsequent use of his name as a kingly title with religious undertones. ${ }^{102}$

\section{III.1.2 Aristocratic Identity}

Below the level of the crown, our understanding of the social structure of the Arsakid Empire is hazy. Classical sources do not provide a clear picture of the aristocracy, but tend to differentiate broadly between groups holding varying degrees of freedom, using what seems to be a framework borrowed from the Mediterranean to describe the Parthian system. ${ }^{103}$

Roman sources report a Parthian aristocratic council that served an advisory role within the empire, though the details of its structure and function vary. In one reference, Justin describes an ordo of the nobles who served as military commanders and political leaders, while elsewhere he refers to a Parthian senatus. ${ }^{104}$ Poseidonios apud Strabo describes a bicameral council of the Parthians, ${ }^{105}$ composed of members of the hereditary aristocracy on the one hand, and wise men and priests on the other. ${ }^{106}$

Better evidence for the structure of the aristocracy comes from the Sasanian period, when there is inscriptional evidence for a four-fold division of the elite, with subdivisions delineating the most important noble families. ${ }^{107}$ It is hypothesized that the Arsakid system functioned in a similar way. ${ }^{108}$ The continuities may have

101 On dynastic cult sites, Canepa 2018, 235-239.

102 Ammianus Marcellinus (Amm. Marc.) 23. 6. 4-6. Olbrycht 2016b, 102.

103 Lukonin 1983, 683-684.

104 Just. Epit. 41. 2. 2. The manuscripts for Pomp. Trogus/Justin are confused here: they read either populorum ordo or ipsorum ordo, which has a long history of emendation, including praepositorum ordo or probulorum ordo. See Widengren 1983, 1268 for an argument that populorum ordo is an acceptable Latin version of a term familiar from later Iranian feudalism. The identity of the nobles being referenced in is unclear. Those seeing the Arsakid Empire as strongly nomadic tend to interpret these families as the vestiges of nomadic aristocracy (Olbrycht 1998, 115-117).

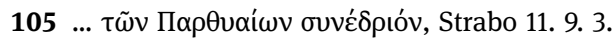

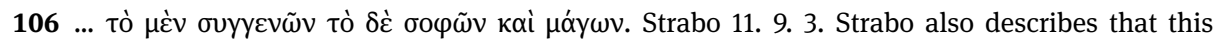
body is responsible for electing the king, chosen from their ranks, although this assertion has been contested, Hauser 2005, 187-192; Lerouge 2007, 250; Wolski 1993, 112.

107 Lukonin 1983, 699.

108 The origin of this internal hierarchy is unclear. Lukonin $(1983,699)$ notes that many of the terms come from known Achaemenid antecedents, suggesting that perhaps the structure can be connected to Achaemenid court practices. Olbrycht (2003, 88-89), however, is skeptical of Achaemenid continuities in the social structure of the Arsakid elite, and suggests that the structures have more in common with steppe mobile pastoralists. 
been quite direct. For instance, several noble families attested in the Sasanian sources - the Sūrens and Kārens - are known to have been important within the Arsakid Empire. ${ }^{109}$ However, the distorted picture in the Greek and Latin sources hinders a total reconstruction of the earlier Arsakid system. ${ }^{110}$

As exemplified in the conflicting stories surrounding the founder of the Arsakid dynasty, the (ethno-)cultural roots of the Parthian lords more broadly have been the subject of much debate, centered around the question of Parthian nomadism. ${ }^{111}$ For a long time, and especially among scholars working in Eastern Bloc countries of the Soviet space, emphasis was placed on their putatively non-Iranian roots and their nomadic character. ${ }^{112}$ However, in the context of modern scholarship, pre-Islamic Iranian cultural belonging is constructed either on linguistic (speakers of an Iranian language), or religious (those who practice Zoroastrianism) grounds. ${ }^{113}$ In both senses, the Parthians fit. The main administrative language of the Arsakid court, Parthian, was an Iranian language, and the dynastic religion of the Arsakids appears to have been an earlier form of Zoroastrianism. ${ }^{114}$

At the same time, it also appears clear that Arsakid power was enabled through close relationships between Parthian aristocrats and members of so-called Scythian mobile pastoralist groups. These alliances - which may indeed have been essentially Parthian cooption of mobile pastoralist mercenaries - are most clearly attested in a coalition that Olbrycht has called the Daho-Hyrkanian group, who maintained considerable autonomy along the Caspian coast and northeastern Iran. ${ }^{115}$ Parthian nobles in alliance with the Dahae presented a formidable base of power, and were the force behind a number of episodes of 'pretenders' to the Arsakid throne through the first century CE. They were also the force behind the ascension of Artabanos II, himself raised among the Dahae. ${ }^{116}$ Although scholars will likely continue to disagree about the depth the Parthians' socio-cultural debt to the nomadic world, the

109 For the Sūrens, see Plut. Crass. 21. 6-7; Tac. Ann. 6. 42. On the Kārens, see Tac. Ann. 12. 10-14. For the families and their appearance in the Sasanian texts, see Lukonin 1983, 704. For debates, see Hauser 2006, 304-307.

110 Compelling arguments have been advanced for parts of the system, see Dąbrowa 2013; Koshelenko 1980; Olbrycht 2003.

111 Some have stressed the predominantly sedentary nature of the Arsakid dynasty and their socio-political world (Boyce 1994; Hauser 2005), while others maintain that nomadic practices had long ramifications (Koshelenko 1966, 1980; Nikonorov 1995; Olbrycht 2003, 2015).

112 It is hard to overlook the role of historiography in this discussion. Much of the archaeological evidence cited in support of nomadic connections was conducted by scholars in the Soviet Union, and therefore more available to russophone scholars. See Fabian, ch. 13, this volume.

113 De Jong 2017.

114 At the same time, there is evidence for the practice of some elements of Zoroastrianism in nonIranian communities within the Arsakid sphere, particularly from the Caucasus, Rapp 2009; Russel 1987.

115 Olbrycht 1998, 161.

116 Tac. Ann. 6. 36. 41-42. 
Dahae demonstrate, at the very least, the ongoing relevance of mobile pastoralist groups in the internal affairs of the Arsakid Empire into the first century CE.

Religion is another category within the Arsakid Empire that shaped the elite, but also cut across other types of social networks. A growing body of evidence, especially from the Nisa ostraca, has demonstrated that the Arsakid kings and elite families practiced Zoroastrianism. ${ }^{117}$ But unlike in the Sasanian period, the religion was not an instrument of state authority. Instead, the practice of Zoroastrianism was more akin to domestic religion, creating a mosaic of locally specific religious instantiations. ${ }^{118}$ Evidence for one such instantiation comes from accounts of elite families in Arsakid Armenia, who included as part of their familial retinue both priests and minstrels connected to the Zoroastrian tradition, who perpetuated both religious and lay knowledge. ${ }^{119}$

At the same time, the empire also accommodated groups that operated within other religious frameworks, which created different networks within the empire. Talmudic sources provide the most abundant evidence for one such group: the Jewish community. Split between Roman and Arsakid space, the accounts suggest that co-religionists bridged the gap between the imperial systems. Their cross-border activity is visible in the Roman historian Josephus's stories about the Arsakid vassal kingdom Adiabene, whose royal family converted to Judaism in the first half of the first century CE. ${ }^{120}$ Finally, cuneiform texts and material evidence also attest to the continuation of older Mesopotamian religious practices. One particularly elucidating example comes from the archive of Rahimesu, documenting the financial administration of a Babylonian temple in 94-93 BCE, where religious practices continued under the Arsakids. ${ }^{121}$

The social practices and political organization of the Arsakid Empire, viewed here through the lenses of kingship, aristocratic self-presentation, and religion, demonstrate the flexibility of the imperial system. Over the course of the centuries, it is possible to identify trends in the ideological frameworks of Arsakid rule, including the intensification of intentionally 'Iranian' representational practices, albeit often ones that represent neo-Persian adaptations and a continued involvement with the mobile pastoralist world. The socio-political system that arose in this context was based on a network of connections between the Arsakid family, their Parthian kinsmen, and a growing circle of elites from Armenia to India.

117 De Jong 2015b, 94-95.

118 De Jong 2008.

119 Boyce 1957, on the gōsān minstrels. On their presence in the court retinue in Armenia, see de Jong 2015a, 127.

120 Josephus Antiquitates Judaicae (Joseph. AJ) 20. 17-96. For Josephus on Adiabene, see Rajak 1998.

121 Van der Spek 1998. 


\section{III.2 Military Force}

A formidable military force facilitated the expansion of both the dynasty and its elite. There are heated debates about the structure of the Arsakid army and the origins of its tactical advantages. ${ }^{122}$ It is clear, however, that military strength played a central role in Arsakid history, from the early days when the Parthians took advantage of the dissolution of Seleukid power, to their later confrontations with Romans and Saka on their borders.

The Parthian military, and particularly its cavalry, is prominent in Roman literary sources, which paint a picture of a mobile fighting force with several specialized heavy-armored troops, most notably the cataphracti/kataphraktoi. ${ }^{123}$ The Parthian armies were also known for their deadly mounted archers, ${ }^{124}$ famous for their ability to shoot backward while at full gallop in the so-called 'Parthian Shot.' ${ }^{125}$ Beyond the esteemed cavalry, the sources also describe infantry of various types, as well as camel-mounted lancemen. ${ }^{126}$

The Parthian army was organized on a decimal system and was what scholars call a composite army. ${ }^{127}$ It included a relatively small standing force under the direct rule of the Arsakid king, ${ }^{128}$ as well as hired mercenaries, especially those drawn from mobile pastoralist communities in the north and northeast of the empire. ${ }^{129}$ Numerically, the strength of the army lay in forces mobilized by the ruling elite in areas under direct Arsakid control, as well as by kings from territories in its suzerainty or in alliance with it. ${ }^{130}$ Within these forces, the sources describe military roles both for the aristocrats themselves and the so-called servi, those dependent on the aristocratic families. Plutarch, for example, provides three separate classes of dependent fighters, the douloi, pelatai and oiketoi, inside of the forces serving one Parthian lord. ${ }^{131}$

122 E.g., Wolski 1981; Hauser 2006; Olbrycht 2015.

123 Plutarch Life of Lucullus (Plut. Luc.) 26-28; Frontinus Strategemata (Frontin. Str.) 2. 2. 4; Appian Mithridateios (App. Mith.) 85. See Potts 2007; Hauser 2006, 300-301.

124 Plut. Crass. 24. 3-27. 1; Tac. Ann. 6. 35. 2.

125 Wissemann 1982 on the 'Parthian shot' in Roman literature.

126 Cass. Dio 40. 15. 2; Appian Bella civilia (App. B Civ.) 2. 18; Herodianos (Hdn.) 4. 14. 3. For more detail on the composition of the army, see Hauser 2006, 297-304.

127 Olbrycht 2016a, 296.

128 Olbrycht (2016a, 299-303) sees the standing forces as specifically a type of 'royal guard,' attested for example in Tac. Ann. 15. 2. 4, as well as in inscriptions, while Hauser considers the standing army to be those "(1) at fortresses for border control and in garrisons and (2) cataphracti ..." (2006, 310-311).

129 Just. Epit. 42. 1. 2; Tac. Ann. 6. 33. 2-3, 6. 36. 3. See Wolski 1965, 107.

130 For an attempt to reconstruct the numerical strength of the Arsakid forces, see Olbrycht 2016a. Although his account differs in many specifics, Hauser 2006, 311 reaches the same conclusion about the proportional scale of the 'standing' vs. levied armies.

131 Plut. Crass. 21; 27. 
That these troops were levied indirectly rather than directly by the Arsakid king has been interpreted as a sign of the weakness of the Arsakid monarch. A central textual locus of this debate is Herodianos 3. 1. 2-3, which describes an episode in which the Arsakid king Vologases V ordered his satrapal commanders to gather troops for battle, rather than relying on either a standing army or mercenaries that he controlled directly. ${ }^{132}$ The organization of the Arsakid army did not follow the Roman model with which Herodianos was familiar, but neither should this system be seen as intrinsically weak. On the contrary, when it functioned well, it enabled the King of Kings to limit military expenditures by procuring troops through indirect channels.

In the early centuries of Arsakid growth, between the reigns of Mithradates I and Mithradates II, the kings were able to use revenues from their newly conquered territories to hire large numbers of mercenary forces. As growth slowed, greater power shifted into the hands of Parthian elites, who increasingly headed fighting forces with the "characteristics of private militias." 133 The Arsakid kings in the late first century BCE and early first century CE were dogged by difficulties arising from these powerful factions, whose interference in imperial succession was a recurrent trope. But eventually, the Arsakid monarchs found a solution, consolidating power within the imperial family. This created a formidable dynastic bulwark stretching from Armenia through northern Mesopotamia and Media, stabilizing the empire and diminishing the power of rival claimant clans. ${ }^{134}$

\section{III.3 Administration, Space, and Movement}

\section{III.3.1 Administration and Territorial Governance}

There does not appear to have been a single, uniform system of territorial control across Arsakid space, nor was there a single policy toward border zones. ${ }^{135}$ Instead, there were several types of territories, including those directly administered by governors appointed from the ranks of the empire's aristocratic families or local elites; frontier regions that seem to have been entrusted to specific caretakers; and allied kingdoms. ${ }^{136}$ The borders seem largely permeable, facilitating a continuation of older networks linking populations across the space.

\footnotetext{
132 Hdn. 3. 1. 2.

133 Gregoratti 2017b, 136-137.

134 Olbrycht 1998, 176-190.

135 In the case of the northern frontiers, recent archaeological work has demonstrated that contrary to previous belief, the Arsakid period did not see the construction of border walls or fortification architecture, unlike in the Sasanian period (Sauer et al. 2012).

136 Wiesehöfer 1999, 99-100 on this formulation. See, for example, the command structures described in Shayegan 2017, 414-415.
} 
A more detailed picture of the Arsakid administrative system in one corner of the empire can be gleaned in Babylonia, where the combination of the Astronomical Diaries and inscriptions provide the richest evidence. In particular, the reports about Babylonia emphasize the importance of cities - a territorial unit with roots in the pre-Arsakid period - within the system. The hierarchy described for Babylonia is multilayered, ${ }^{137}$ with the permanent presence of satrap, as well as generals and garrison commanders with military roles of a more limited operational scope, ${ }^{138}$ all of whom could be presided over by a supreme commander in times of conflict. Some elements of this system appear also to have been in force in Arsakid Dura Europos, suggesting that it may have been common at least in the western Arsakid territories. ${ }^{139}$ A much more granular glimpse into a specific administration/taxation system comes from Nisa, where a collection of ostraca describe officials involved the receipt of taxable foodstuffs (wine) from a specific type of land. ${ }^{140}$ These accounts record the participation of at least three different types of officials, some of whom seem to have had both military and civilian roles within the hierarchy.

An episode of sub-satrapal history from Babylon sheds light on the functioning of this system. ${ }^{141}$ The episode involves two brothers, Anilieos and Asinaios, who edged into power as Jewish rulers in the Babylonian cities of Neardea and Nisibis. Their power grew from ragtag beginnings extracting tribute from local residents after they won a surprising defeat over the Arsakid governor in Babylonia. ${ }^{142}$ In the wake of this upset, rather than siding with his governor or generals, the Arsakid king Artabanos chose to recognize the brothers as the rightful rulers of Babylon, ${ }^{143}$ after which the pair then ruled for 15 years from around the early 20s CE, until they were eventually deposed but by rival Babylonians. In any event, Artabanos's choice to recognize the brothers was an attempt to curb the power of his own officials in the region, ${ }^{144}$ and reflects the complicated flows of power under the Great King.

Beyond lands controlled in these ways, the Arsakid Empire also included a number of vassal kingdoms like Adiabene, Hyrkania, Charakene and Elymais,

137 Shayegan 2011, 208-221.

138 There has been a suggestion that the Arsakid system continued a practice from the Seleukid period, where Greek citizens in major cities had their own general appointed by the king from their number and who was responsible both for the typical administrative duties of the city's protection, but also for raising Greek troops (Shayegan 2011, 213).

139 Shayegan 2011, 215-219.

140 For ostraca related to vineyards and the uzbari ('wzbry) estates, see Diakonoff and Livshits 1977, 1.2.1.

141 Joseph. AJ 18. 310-70. The story is embedded in Josephus's longer moralizing tale of why the Jews at Seleukeia were massacred, but is thought to be historical. See Rajak 1998.

142 Fowler 2007.

143 Joseph. AJ 18. 337.

144 Joseph. AJ 18. 330. 
whose rulers retained considerable autonomy. ${ }^{145}$ De Jong has termed these flanking kingdoms the "Parthian Commonwealth" in recognition of the fact that these spaces were participating not only in a political Arsakid sphere, but more broadly in a culturally Parthian one. ${ }^{146}$ These local dynasts had the right to carry out local and regional functions like appointing judges, setting prices, and collecting duties, and sometimes even minting coinage. ${ }^{147}$ The kingdoms paid tribute and levied troops when requested. ${ }^{148}$ This distributed power structure allowed the empire to grow exceptionally quickly, and spared the central authority from needing to concern itself with the array of minor conflicts that transpired on its borders.

Evidence does not allow for the creation of a universal picture of relationships between the King of Kings and the rulers of the allied kingdoms. However, the glimpses that are possible suggest that Arsakid dynasts held power by balancing the interests of local dynasts with those of other powerful constituent groups within the spaces and harnessing these diverse groups to maintain their own power. The result was a hierarchy that distributed power horizontally across geographically disbursed regional authorities. ${ }^{149}$ There was, however, a shift over time, with local dynasts increasingly replaced by members of the Arsakid family from the time of Vologases I onward, providing greater centralization of power in the royal family, if not in the King of Kings himself. ${ }^{150}$ Thus, by the early second century CE, the son of Pakoros and brother of Vologases II had been installed on the throne in Charakene, while the thrones of Elymais and Media Atropatene both moved into the hands of Arsakid-connected dynasts. ${ }^{151}$

\section{III.3.2 Architecture and Urbanism}

The expansion of the Arsakid Empire also brought material changes to territories under its control. In general, however, as with the structure of the empire itself, there was significant local variation in the nature and extent of the large- and smallscale transformations of material culture. Nevertheless, the spread of imperial architectural forms, and particularly the barrel-vaulted hall or ayvan, would go on to

145 Pliny (HN 6. 112) reports that, in the first century CE, there were 18 kingdoms (regna) of the Parthians, although some have taken the term regna to be the term for Arsakid satrapies more generally (Dąbrowa 2012, 180).

146 De Jong 2013a, 155-159.

147 See, for example, the case of the exilarchs of the Judaeans (Lukonin 1983, 728). On coinage, see also the situation in Fars, Wiesehöfer 2007.

148 Olbrycht 2016a, on the importance of their troops to the overall Arsakid fighting force.

149 Fowler 2010, 75-77 develops the idea of horizontal distribution of power in the context of a hierarchal system.

150 Hauser 2006, 307; Gregoratti 2017a, 101.

151 Gregoratti 2017a, 100-101. 
have long-reaching consequences for the future development of Persian architecture. ${ }^{152}$

There are some textual accounts of Arsakid urban foundations, which report, for example, the early city-building and fortification activities of Arsakes, and the founding of Vologesias by Vologases I. ${ }^{153}$ But most data for understanding Parthian settlement patterns and urbanism are archaeological, and are both laconic and unevenly dispersed. The most intensive work of settlement and urban archaeology of the Arsakid period has been conducted in Mesopotamia. Many of the older cities in the area, such as Seleukeia, Babylon, Nippur, and Uruk, saw at least some growth in the wake of Arsakid expansion, and also considerable ruptures with pre-Arasakid usages of space. ${ }^{154}$ Beyond the spatial renegotiations, the Arsakid period also saw the emergence of distinct and un-Babylonian forms of religious architecture, as in the case of the Gareus temple, constructed in the early second century CE. It combines a Greek dedicatory inscription with a ground plan and decorative details that drew on both Babylonian and Hellenistic traditions. ${ }^{155}$

Outside of Babylonia, some of the strongest archaeological evidence for shifts brought by Parthian presence comes from areas within Elymais, particularly those discovered in the course of long-running excavations at Susa, where the Arsakid period was also one of considerable wealth and expansion. ${ }^{156}$ The productive potential of the city and its hinterland was enhanced by the Arsakid presence, as evidenced by a Greek-language dedicatory inscription to an Arsakid strategos, Zamaspes, set up on behalf of the city's citizenry to commemorate his role in the expansion of irrigation works. ${ }^{157}$ Evidence of expansion and the flourishing of settlement can be seen in Northern Mesopotamia, which saw marked expansion in the scale of previously existing settlements along the Euphrates. ${ }^{158}$ Suggestive of the economic expansion of the Arsakid period, smaller scale Arsakid-period sites in Elymais have been noted to cluster along trade routes, including both the older Achaemenid royal road and routes known to have been in use in the Islamic period. ${ }^{159}$ This pattern is not uniform, however, since farther north in the Dehlorān plain of northern Khūzestān, archaeological survey has demonstrated that Arsakid-period sites were not located along what are presumed to be central routes, but were instead disbursed. ${ }^{160}$

152 See for example the detailed study of regionalism in ceramic styles in Haerinck 1983.

153 Especially Chaumont 1974.

154 For overviews: Canepa 2018, 81-94; Hauser 2012, 1007. For Nippur, see Crawford 1959; Knudstad 1968; Keall 1975. On Uruk, see Adams and Nissen 1972.

155 Kose 1998, 291-335. See also Downey 1988, 137-143.

156 Miroschedji, Desse-Berset, and Kervran 1987, 51.

157 Cumont 1931, 249; Shayegan 2011, 209-211.

158 Hauser 2017b, 238-239.

159 Moghaddam and Miri 2007, 45-48.

160 Neely 2016, 258. 
Beyond the developments in urban systems, a number of sites also demonstrate the development of regional palace architecture or elite villa architecture. ${ }^{161} \mathrm{Al}$ though the dating of many of these structures has presented a persistent problem, new archaeological work, as well as reassessments of earlier excavations, have uncovered a body of elite architecture that is increasingly recognizable as specifically Parthian. These sites set new precedents in architecture - particularly the use of the ayvan, or barrel-vaulted hall - that were influential in the later development of Persian architectural forms. ${ }^{162}$

\section{III.3.3 Movement through the Empire and Trade Relations}

The networks that developed as a result of the complex political system described above covered the land stretching from the edges of the Mediterranean world, through the heartland of the ancient societies of the Near East, and then farther toward Central Asia, India, and China. The Arsakid Empire created conditions that facilitated organized trade across these corridors, although the perception that Parthians were middlemen in direct Roman-Chinese trade is widely rejected today. ${ }^{163}$

Evidence of Arsakid-era movement along east-west routes is preserved in surviving fragments of the work of Isidoros of Charax, known as the Stathmoi Parthi$k o i .{ }^{164}$ The text provides something of an itinerary and a description of Arsakid territories from Zeugma at the eastern edge of Anatolia to Central Asia, moving along the Euphrates corridor to Seleukeia before turning in to the Zagros highlands and the eastern territories of Hyrkania and Khorāsān. ${ }^{165}$ Detailed itineraries from the Achaemenid period attest to the existence of an official 'royal road' running along much of the same path, particularly in Mesopotamia. In both the Achaemenid and Arsakid periods, Seleukeia-Tigris was a node, articulating interactions between the highlands, Mesopotamia, and the Persian Gulf. ${ }^{166}$ The movement of the Arsakid seat to this city in the mid-second century BCE likely reflects its value in this sense. The foundation of Vologesias nearby in the first century CE shows the continued relevance of the area and the desire of the later Arsakid monarchs to direct more of the profits of the trading activity to the royal treasury by circumventing the entrenched interest groups in Seleukeia. ${ }^{167}$

\footnotetext{
161 Canepa 2018, 315-323.

162 Canepa 2018, 316-317.

163 Rezakhani 2010.

164 Isidoros of Charax, born in the capital of Charakene, likely wrote in the early first century CE, Hartmann 2017; Schuol 2017.

165 Hauser 2017a elaborates on the different sections of the text.

166 Strabo 16. 2. 5; Plin. HN 6. 122.

167 Keall 1975 discusses the growing commercial interests of the Arsakid kings in this period.
} 
The role of cities in both Babylonia and Charakene within global trade systems is made clearer in the long-term presence of Palmyrene merchants along the Euphrates. ${ }^{168}$ The Palmyrene traders, who operated lucrative caravan trade across the Syrian desert, left a number of inscriptions at Palmyra attesting to their presence in what might be understood as Palmyrene trading colonies in Arsakid territories in the Tigris-Euphrates basin, particularly in the capital of Charakene, Spasinou Charax (an important node in the Indian Ocean trade routes), as well as Vologesias, Seleukeia, Babylon, and other smaller cities. The epigraphic testimony attests not only to the presence of these merchants, but to their active roles in the civic life of cities under Arsakid control where they engaged in what can be seen as Hellenistic forms of civic generosity. The presence of these Palmyrene communities at Vologesias, well after the Arsakid kings started to take a more active role in managing the trade networks of their empire, demonstrates that the Arsakids did not intend to develop a trade monopoly of their own, but rather an infrastructure through which they could extract profit. The eventual terminus of the Palmyrene trading routes at cities on the coast of the Persian Gulf suggests a maritime component of the Parthian trade infrastructure. ${ }^{169}$

Several accounts from Chinese sources, the Shiji, Hanshu, and Hou Hanshu, also highlight the importance of trade within the Arsakid Empire (Anxi) from a Chinese perspective. ${ }^{170}$ One account from 121 BCE comes from the biography of the emissary Zhang Qian, transmitted in the wake of early direct contacts between the Chinese and Arsakid courts. ${ }^{171}$ In this description, the Arsakid lands are described as vast, cultivated, and developed, with hundreds of towns both large and small, with "trading places" and merchants who "travel in carts and ships" deep into the territory of their neighbors, using silver money minted by the state. ${ }^{172}$

Two later episodes in the Hou Hanshu describe what may be Parthian attempts to control trade across their space by inhibiting the development of direct RomanChinese diplomatic relationships. The first episode dates to ca. $97 \mathrm{CE}$, when the Chinese emissary Gan Ying sought to reach Da Qin, or the Roman Empire. ${ }^{173}$ Gan Ying made it as far as a port called Tiaozhi, identified by some as Charakene. ${ }^{174} \mathrm{He}$ was then told by his Parthian interlocutors that the sea journey was long and risky, and decided not to attempt it. A second account from 166 CE expresses clear eco-

168 Matthews 1984, 166. On the role of Palmyrene trade in the Near East more generally, see Seland 2014.

169 Millar 1998; Seland 2011; Gregoratti 2019. See Dwivedi, ch. 2, sec. VI.2, this volume for a discussion of so-called torpedo jars and their misinterpretation.

170 Posch 1998. On the context of these sources, see also Morris, ch. 9, this volume.

171 Shiji 123, see Posch 1998, 358-359, 2.1.1-2.1.5.

172 Shiji 123.3161.

173 Hou Hanshu 88.2918; see also Gregoratti 2019, 57-59.

174 This identification is much debated. See the recent discussion in Zanous and Yang 2018, 133134. 
nomic motives for Parthian interference in the establishment of direct Roman-Chinese diplomatic relations, saying that the Parthians "put obstacles" in the way of the Romans, wishing themselves "to trade with them [the Romans] in Chinese silk." 175

The question of how far these sources can be extrapolated in an effort to understand Parthian trade interests remains debated. ${ }^{176}$ It seems clear, though, that both Roman and Chinese sources viewed the Parthians as an important link in overland and maritime trade between the Mediterranean and East Asian spheres. How the Arsakid dynasts and Parthian elites themselves understood this position is, unfortunately, less clear.

\section{Conclusion: Arsakid Potentials: (Re)configurations of Networks}

The Arsakid Empire is a slippery phenomenon. Its decentralized structure and diverse communities were a key source of imperial strength, allowing dynasts to draw on diverse models of rule in their imperial project and to pivot quickly when facing changing historical circumstances. These same structural characteristics, however, ensured that centrifugal forces were never far from the surface, threatening to destabilize the imperial network.

Arsakid rule generally allowed the communities under its dominion to retain their own cultural practices, and as a result supported a bewildering diversity within its borders. Arsakid kings, particularly in the early days of imperial expansion, were comfortable integrating local elites from across the empire into their imperial administration. As a result, preexisting networks maintained their relevance and were even elevated as they came to participate in the more expansive political context afforded by the Arsakid hegemony. Although it is possible to glimpse the growth of a Parthian cultural koine (community) in the period, it never entirely supplanted local practices, and there cannot be said to have been a uniform 'Arsakid' cultural program, nor indeed a single Arsakid culture.

The lasting legacy of the empire, however, was far-reaching, stretching well past the borders of the empire, from Anatolia to eastern Central Asia. The empire created a shared political community across this tremendous territory, in which local nodes were empowered to conduct their affairs with relatively little direct oversight. Instead, both diplomacy and trade happened along a web of interactions that connected the Arsakid dynasts to their far-flung kinsmen and nobles, joined by cultural patterns rather than by statutory bonds.

175 Hou Hanshu 99.2920.

176 Alram 2004; Gregoratti 2014; Wiesehöfer 2016; ch. 11, this volume. 


\section{References}

Adams, R. McC., and H. J. Nissen. 1972. The Uruk countryside: The natural setting of urban societies. Chicago, IL: University of Chicago Press.

Alram, M. 1998. "Stand und Aufgaben der arsakidischen Numismatik." In Wiesehöfer (1998), 365-388.

-. 2004. "The history of the Silk Road as reflected in coins." Parthica 6, 47-68.

Assar, G. F. 2006a. "A revised Parthian chronology of the period 91-55 BC.” Parthica 8, 55-104.

-. 2006b. "A revised Parthian chronology of the period 165-91 BC." Electrum 11, 87-158.

-. 2009. "Some Remarks on the chronology and coinage of the Parthian 'Dark Age." Electrum 15, 195-234.

Bivar, A. D. H. 1983. "The political history of Iran under the Arsacids." In E. Yarshater (ed.), The Cambridge history of Iran. Vol. 3.1, 21-99. Cambridge: Cambridge University Press.

-. 2007. "Gondophares and the Indo-Parthians." In V. S. Curtis and S. Stewart (eds.), Age of the Parthians, 26-36. London: I. B. Tauris.

Bollati, A. 2008. "Le sculture in argilla cruda dipinta." In Invernizzi and Lippolis (2008), 167-196. Bosworth, A. B. 1977. "Arrian and the Alani." Harvard Studies in Classical Philology 81, 217-255.

Boyce, M. 1957. "The Parthian Gōsān and Iranian minstrel tradition." Journal of the Royal Asiatic Society 89.1-2, 10-45.

-. 1983. "Parthian writings and literature." In E. Yarsahter (ed.), The Cambridge history of Iran. Vol. 3.2, 1151-1165. Cambridge: Cambridge University Press.

-. 1994. "The sedentary Arsacids." Iranica Antiqua 29, 241-251.

Canepa, M. P. 2017. "Rival images of Iranian kingship and Persian identity in post-Achaemenid western Asia." In R. Strootman and M. J. Versluys (eds.), Persianism in antiquity, 200-222. Stuttgart: Franz Steiner.

-. 2018. The Iranian expanse: Transforming royal identity through architecture, landscape, and the built environment, 550 BCE-642 CE. Berkeley, CA: University of California Press.

Chaumont, M.-L. 1973. "Études d'histoire parthe. II: Capitales et résidences des premiers Arsacides (Ille-ler s. av. J.-C.).” Syria 50, 197-222.

-. 1974. "Études d'histoire parthe. III: Les villes fondées par les Vologèse." Syria 51, 75-89.

Crawford, V. E. 1959. "Nippur, the holy city." Archaeology 12.2, 74-83.

Cumont, F. 1931. "Inscriptions grecques de Suse." Comptes rendus des séances de l'Académie des Inscriptions et Belles-Lettres 75.3, 233-250.

Curtis, V. S. 1998. "The Parthian costume and headdress." In Wiesehöfer (1998), 61-74.

-. 2007. "The Iranian revival in the Parthian period." In V. S. Curtis and S. Stewart (eds.), Age of the Parthians, 8-25. London: I. B. Tauris.

Dąbrowa, E. 1998. “Philhellên: Mithridate ler et les Grecs.” In E. Dąbrowa (ed.), Ancient Iran and the Mediterranean world: Proceedings of an international conference in honour of Professor Józef Wolski held at the Jagiellonian University, Cracow, in September 1996, 9-17. Krakow: Jagiellonian University Press.

-. 2009. "Mithradates I and the beginning of the ruler-cult in Parthia." Electrum 15, 41-51.

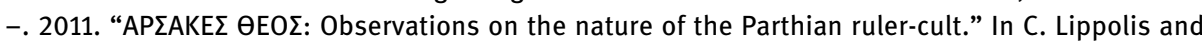
S. de Martino (eds.), Un impaziente desiderio di scorrere il mondo: Studi in onore di Antonio Invernizzi per il suo settantesimo compleanno, 247-253. Florence: Le lettere.

-. 2012. "The Arsacid Empire." In T. Daryaee (ed.), The Oxford handbook of Iranian history, 164186. Oxford: Oxford University Press.

-. 2013. "The Parthian aristocracy: Its social position and political activity." Parthica 15, 53-62.

-. 2014. "A troublesome vassal? Elymais and Parthia (141 BC-AD 228)." Parthica 16, 61-68.

-. 2018. "Arsacid dynastic marriages." Electrum 25, 73-83.

De Jong, A. 2008 [2012]. "Regional variation in Zoroastrianism: The case of the Parthians." Bulletin of the Asia Institute 22, 17-27. 
-. 2013a. "Hatra and the Parthian commonwealth.” In L. Dirven (ed.), Hatra: Politics, culture and religion between Parthia and Rome, 143-160. Stuttgart: Franz Steiner.

-. 2013b. “Religion in Iran: The Parthian and Sasanian periods (247 BCE-654 CE)." In W. Adler and M. A. Sweeney (eds.), The Cambridge history of religions in the ancient world. Vol. 2, 23-53. Cambridge: Cambridge University Press.

-. 2015a. "Armenian and Georgian Zoroastrianism.” In M. Stausberg and Y. S.-D. Vevaina (eds.), The Wiley Blackwell companion to Zoroastrianism, 119-128. Malden, MA: Wiley-Blackwell.

-. 2015b. "Religion and politics in pre-Islamic Iran.” In M. Stausberg and Y. S.-D. Vevaina (eds.), The Wiley Blackwell companion to Zoroastrianism, 83-101. Malden, MA: Wiley-Blackwell.

-. 2017. "Being Iranian in antiquity (at home and abroad)." In R. Strootman and M. J. Versluys (eds.), Persianism in antiquity, 35-47. Stuttgart: Franz Steiner.

Diakonoff, I. M., and V. A. Livshits. 1976-2001. Corpus Inscriptionum Iranicarum. Part 2, vol. 2.1, Parthian Economic Documents from Nisa. 6 vols. London: School of Oriental and Asian Studies.

Dirven, L. 2016. “The problem with Parthian art at Dura.” In T. Kaizer (ed.), Religion, society and culture at Dura-Europos, 68-88. Cambridge: Cambridge University Press.

Downey, S. B. 1988. Mesopotamian religious architecture: Alexander through the Parthians. Princeton, NJ: Princeton University Press.

Fisher, W. B. 1968. "Physical geography.” In W. B. Fisher (ed.), The Cambridge history of Iran. Vol. 1, 3-110. Cambridge: Cambridge University Press.

Fowler, R. 2005. “'Most fortunate roots': Tradition and legitimacy in Parthian royal ideology.” In O. Hekster and R. Fowler (eds.), Imaginary kings: Royal images in the ancient Near East, Greece and Rome, 125-155. Stuttgart: Franz Steiner.

-. 2007. "Kingship and banditry: The Parthian Empire and its western subjects." In T. Rajak (ed.), Jewish perspectives on Hellenistic rulers, 147-162. Berkeley, CA: University of California Press.

-. 2010. “King, Bigger King, King of Kings: Structuring power in the Parthian world.” In T. Kaizer and M. Facella (eds.), Kingdoms and principalities in the Roman Near East, 57-77. Stuttgart: Franz Steiner.

-. 2017. "Cyrus to Arsakes, Ezra to Izates: Parthia and Persianism in Josephus.” In R. Strootman and M. J. Versluys (eds.), Persianism in antiquity, 355-380. Stuttgart: Franz Steiner.

Frye, R. N. 2004. "Parthians in the East." Parthica 6, 129-132.

Ghirshman, R. 1962. Persian art: The Parthian and Sassanian dynasties, 249 BC-AD 651. S. Gilbert and J. Emmons (trans.) New York, NY: Golden Press.

Gregoratti, L. 2013. "The journey east of the Great King: East and West in the Parthian kingdom." Parthica 15, 43-52.

-. 2014. "The Parthian Empire: Romans, Jews, Greeks, nomads and Chinese on the Silk Road." In M. N. Walter and J. P. Ito-Adler (eds.), The Silk Road: Interwoven history. Vol. 1, 43-70. Cambridge: Cambridge Institutes Press.

-. 2017a. "Sinews of the other empire: The Parthian Great King's rule over vassal kingdoms." In H. Teigon and E. Seland (eds.), Sinews of empire, 95-104. Oxford: Oxbow.

-. 2017b. “The Arsacid Empire.” In T. Daryaee (ed.), King of the seven climes: A history of the ancient Iranian world (3000 BCE-651 CE), 125-153. Irvine, CA: UCI Jordan Center for Persian Studies.

-. 2019. "Indian Ocean trade: The role of Parthia." In M. A. Cobb (ed.), The Indian Ocean trade in antiquity: Political, cultural and economic impacts, 66-86. London: Routledge.

Hackl, U., B. Jacobs, and D. Weber, eds. 2010. Quellen zur Geschichte des Partherreiches: Textsammlung mit Übersetzungen und Kommentaren. 3 vols. Göttingen: Vandenhoeck \& Ruprecht.

Haerinck, E. 1983. La céramique en Iran pendant la période parthe (ca. 250 av. JC à ca. 225 après JC): Typologie, chronologie et distribution. Gent: Iranica Antiqua. 
Hansman, J. 1981. "The measure of Hecatompylos." Journal of the Royal Asiatic Society, no. 1, 3-9.

Hansman, J., and D. Stronach. 1974. "Excavations at Shahr-i Qūmis, 1971." Journal of the Royal Asiatic Society, no. 1, 8-22.

Hartmann, U. 2017. "Die Parthischen Stationen des Isidor von Charax: Eine Handelsroute, eine Militärkarte oder ein Werk geographischer Gelehrsamkeit?" In Wiesehöfer and S. Müller (1017), 87-126.

Hauser, S. R. 2005. "Die ewigen Nomaden? Bemerkungen zu Herkunft, Militär, Staatsaufbau und nomadischen Traditionen." In B. Meißner, O. Schmitt, and M. Sommer (eds.), KriegGesellschaft-Institutionen: Beiträge zu einer vergleichenden Kriegsgeschichte, 163-208. Berlin: Akademie-Verlag.

-. 2006. "Was there no paid standing army? A fresh look on military and political institutions in the Arsacid Empire." In M. Mode and J. Tubach (eds.), Arms and armour as indicators of cultural transfer: The steppes and the ancient world from Hellenistic times to the early Middle Ages, 295-319. Wiesbaden: Reichert.

-. 2012. "The Arsacid (Parthian) Empire." In D. T. Potts (ed.), A companion to the archaeology of the ancient Near East. Vol. 2, 1001-1020. Malden, MA: Wiley-Blackwell.

-. 2017a. "Isidor von Charax $\Sigma \tau \alpha \theta \mu o i$ П $\alpha \rho \theta ı$ ikoi: Annäherungen an den Autor, den Routenverlauf und die Bedeutung des Werkes." In Wiesehöfer and Müller (2017), 127-187.

-. 2017b. "Post-imperial Assyria." In E. Frahm (ed.), A companion to Assyria, 229-246. Malden, MA: Wiley-Blackwell.

Hyland, J. 2013. "Vishtaspa krny: An Achaemenid military official in 4th-century Bactria." Achaemenid Research on Texts and Archaeology, no. 2, 1-7.

Invernizzi, A. 1997. "Parthian Nisa: New lines of research." Iran and the Caucasus 1, 107-119.

-. 2001. "Arsacid dynastic art." Parthica 3, 133-157.

-. 2011. "Parthian art - Arsacid art." Topoi 17.1, 189-207.

-. 2016. "A note on architectural traditions in Arsacid Parthia: The round hall at Nisa." In V. S. Curtis, M. Alram, T. Daryaee, and E. Pendleton (eds.), The Parthian and early Sasanian Empires: Adaptation and expansion: Proceedings of a conference held in Vienna, 14-16 June 2012, 83-89. Oxford: Oxbow.

Invernizzi, A., and C. Lippolis, eds. 2008. Nisa Partica: Ricerche nel complesso monumentale arsacide 1990-2006. Florence: Le lettere.

Karras-Klapproth, M. 1988. Prosopographische Studien zur Geschichte des Partherreiches auf der Grundlage antiker literarischer Überlieferung. Bonn: Habelt.

Kawami, T. S. 1987. Monumental art of the Parthian period in Iran. Leiden: Brill.

Keall, E. J. 1975. "Parthian Nippur and Vologases' southern strategy: A hypothesis." Journal of the American Oriental Society 95.4, 620-632.

-. 1994. "How many kings did the Parthian King of Kings rule?" Iranica Antiqua 29, 253-272.

Kharmatta, Іа. 1965. “Из истории алано-парфянских отношений” [From the history of AlanoParthian relations]. Acta Antiqua Academiae Scientiarum Hungaricae 13, 127-147.

Knudstad, J. 1968. "A preliminary report on the 1966-67 excavations at Nippur." Sumer 24, 95-106.

Kose, A. 1998. Uruk: Architektur IV: Von der Seleukiden- bis zur Sasanidenzeit. 2 vols. Mainz: Philipp von Zabern.

Koshelenko, G. А. 1966. Культура Парфии [The culture of Parthia]. Москва: Наука.

-. 1980. "Les cavaliers Parthes: Aspects de la structure sociale de la Parthie." Dialogues d'histoire ancienne 6, 177-199.

Koshelenko, G. A., and V. N. Pilipko. 1994. "Parthia." In J. Harmatta (ed.), History of civilizations of Central Asia. Vol. 2, 131-150. Paris: UNESCO Publications.

Landskron, A. 2005. Parther und Sasaniden: Das Bild der Orientalen in der römischen Kaiserzeit. Vienna: Phoibos. 
Le Rider, G. 1965. Suse sous les Séleucides et les Parthes: Les trouvailles monétaires et l'histoire de la ville. Paris: Geuthner.

Lerner, J. D. 1999. The impact of Seleucid decline on the Eastern Iranian Plateau: The foundations of Arsacid Parthia and Graeco-Bactria. Stuttgart: Franz Steiner.

Lerouge, C. 2007. L'image des Parthes dans le monde gréco-romain: Du début du ler siècle av. J.-C. jusqu'à la fin du Haut-Empire romain. Stuttgart: Franz Steiner.

Loginov, S. D., and A. B. Nikitin. 1996 [1998]. "Parthian coins from Margiana: Numismatics and history." Bulletin of the Asia Institute 10, 39-51.

Lukonin, V. G. 1983. "Political, social and administrative institutions: Taxes and trade." In E. Yarshater (ed.), The Cambridge history of Iran. Vol. 3.2, 681-746. Cambridge: Cambridge University Press.

Marciak, M. 2017. Sophene, Gordyene, and Adiabene: Three regna minora of northern Mesopotamia between East and West. Leiden: Brill.

Masson, M. E., and G. A. Pugacenkova. 1982. The Parthian rhytons of Nisa. C. M. Breton Bruce (trans.), Florence: Le lettere.

Mathiesen, H. E. 1992. Sculpture in the Parthian Empire: A study in chronology. 2 vols. Aarhus: Aarhus University Press.

Matthews, J. F. 1984. "The tax law of Palmyra: Evidence for economic history in a city of the Roman East." Journal of Roman Studies 74, 157-180.

Millar, F. 1998. "Caravan cities: The Roman Near East and long-distance trade by land." In M. Austin, J. Harries, and C. Smith (eds.), Modus Operandi: Essays in honour of Geoffrey Rickman, 275-299. London: Institute of Classical Studies.

Miroschedji, P. de, N. Desse-Berset, and M. Kervran. 1987. "Fouilles du chantier ville royale II à Suse (1975-1977) II: Niveaux d'époques achéménide, séleucide, parthe et islamique." Cahiers de la Délégation archéologique française en Iran 15, 11-143.

Moghaddam, A., and N. Miri. 2007. "Archaeological surveys in the 'Eastern Corridor,' SouthWestern Iran." Iran 45, 23-55.

Mørkholm, 0. 1980. "The Parthian coinage of Seleucia on the Tigris, c. 90-55 BC." Numismatic Chronicle 20, 33-47.

Neely, J. A. 2016. "Parthian and Sasanian settlement patterns on the Deh Luran Plain, Khuzistan Province, southwestern Iran." Iranica Antiqua 51, 235-300.

Nikonorov, V. P. 1995. “К вопросу о парфянской тактике (на примере битвы при Каррах)” [On the question of Parthian tactics (on the basis of the Battle of Carrhae)]. In Военное дело и средневековая археология Центральной Азии, 53-61. Кемерово.

Olbrycht, M. J. 1998. Parthia et ulteriores gentes: Die politischen Beziehungen zwischen dem arsakidischen Iran und den Nomaden der eurasischen Steppen. Munich: tuduvVerlagsgesellschaft.

-. 2003. "Parthia and nomads of Central Asia: Elements of steppe origin in the social and military developments of Arsacid Iran.” In I. Schneider (ed.), Militär und Staatlichkeit. Beiträge des Kolloquiums am 29. und 30.04. 2002, 69-109. Halle (Saale): Orientwissenschaftliches Zentrum, Martin-Luther-Universität Halle-Wittenberg.

-. 2013. "The titulature of Arsaces I, king of Parthia." Parthica 15, 63-74.

-. 2015. "Arsacid Iran and the Nomads of Central Asia - ways of cultural transfer." In J. Bemmann and M. Schmauder (eds.), Complexity of interaction along the Eurasian steppe zone in the first millennium CE, 333-390. Bonn: Vor- und Frühgeschichtliche Archäologie, Rheinische Friedrich-Wilhelms-Universität Bonn.

-. 2016a. "Manpower resources and army organisation in the Arsakid Empire." Ancient Society 46, 291-338.

-. 2016b. "The sacral kingship of the early Arsacids I: Fire cult and kingly glory." Anabasis 7, 91-106. 
-. 2016c. "Vologases I, Pakoros II and Artabanos III: Coins and Parthian history." Iranica Antiqua 51, 215-233.

Pappalardo, E. 2010. Nisa Partica: I rhyta ellenistici. Florence: Le lettere.

Perevalov, S. M. 2006. “Аланский набег 136 г. н. э. в страны Закавказья: проблемные вопросы" [The Alan raid in 136 CE into the countries of the Transcaucasus: Problematic issues]. In Античная цивилизация и варвары, 318-355. Москва: Наука.

Pilipko, V. N. 1989. “К вопросу о локализации Парфавнисы” [On the question of the localization of Parthian Nisa]. Известия Академии наук Туркменской ССР. Серия общественных наук, no. 2, 17-25.

-. 2001. Старая Ниса: Основные итоги археологического изучения в советский период [Old Nisa: The principal results of archaeological research in the Soviet period]. Москва: Наука.

-. 2008. "The central ensemble of the fortress Mihrdatkirt: Layout and chronology." Parthica 10, 35-51.

Posch, W. 1998. “Chinesische Quellen zu den Parthern.” In Wiesehöfer (1998), 355-364.

Potts, D. T. 1999. The archaeology of Elam: Formation and transformation of an ancient Iranian state. Cambridge: Cambridge University Press.

-. 2002. "Five episodes in the history of Elymais, 145-124 BC: New data from the astronomical diaries." In P. Huyse (ed.), Iran: Questions et connaissances: Actes du IVe congrès européen des études iraniennes oraganisé par la Societas Iranologica Europaea, Paris, 6-10 Septembre 1999. Vol. 1, 349-362. Paris: Association pour l'avancement des études iraniennes.

-. 2007 [2012]. "Cataphractus and Kamāndār: Some thoughts on the dynamic evolution of heavy cavalry and mounted archers in Iran and Central Asia." Bulletin of the Asia Institute 21, 149158.

Pugachenkova, G. A. 1971. Скульптура Халчаяна [The sculpture of Khalchaiana]. Москва: Искусство.

Rajak, T. 1998. "The Parthians in Josephus.” In Wiesehöfer (1998), 309-324.

Rapp, S. H. 2009. "The Iranian heritage of Georgia: Breathing new life into the pre-Bagratid historiographical tradition." Iranica Antiqua 44, 645-692.

Rezakhani, K. 2010. "The road that never was: The Silk Road and trans-Eurasian exchange." Comparative Studies of South Asia, Africa and the Middle East 30.3, 420-433.

Rose, C. B. 2005. "The Parthians in Augustan Rome." American Journal of Archaeology 109.1, 21-75.

Rostovtzeff, M. I. 1935. Dura and the problem of Parthian art. New Haven, CT: Yale University Press.

Russel, J. R. 1987. Zoroastrianism in Armenia. Cambridge, MA: Harvard University Press.

Sauer, E. W., H. O. Rekavandi, T. Wilkinson, and J. Nokandeh. 2012. "Innovation at Persia's frontiers: Sasanian campaign bases and defensive barriers." In L. Vagalinski and N. Sharankov (eds.), Limes XXII: Proceedings of the 22nd International Congress of Roman Frontier Studies, Ruse, Bulgaria, September 2012, 327-331. Sofia: National Archaeological Institute with Museum.

Schlude, J. M., and A. J. Overman. 2017. "Herod the Great: A Near Eastern case study in RomanParthian politics." In J. M. Schlude and B. Reubin (eds.), Arsacids, Romans and local elites: Cross-cultural interactions of the Parthian Empire, 93-110. Oxford: Oxbow.

Schlumberger, D. 1970. L'Orient hellénisé: L'art grec et ses héritiers dans l'Asie non méditerranéenne. Paris: Albin Michel.

Schuol, M. 2000. Die Charakene: Ein mesopotamisches Königreich in hellenistisch-parthischer Zeit. Stuttgart: Franz Steiner.

-. 2017. "Isidor von Charax und die literarische Gattung der stathmoi." In Wiesehöfer and Müller (2017), 71-86. 
Seland, E. H. 2011. "The Persian Gulf or the Red Sea? Two axes in ancient Indian Ocean trade, where to go and why." World Archaeology 43.3, 398-409.

-. 2014. "The organisation of the Palmyrene caravan trade." Ancient West and East 13, 197-211.

Sellwood, D. 1980. An introduction to the coinage of Parthia. London: Spink.

Shayegan, M. R. 2011. Arsacids and Sasanians: Political ideology in post-Hellenistic and Late Antique Persia. Cambridge: Cambridge University Press.

-. 2017. "Persianism: Or Achaemenid remembrances in the Iranian and Iranicate world(s) of antiquity.” In R. Strootman and M. J. Versluys (eds.), Persianism in Antiquity, 401-455. Stuttgart: Franz Steiner.

Simonetta, A. M. 2001. "A proposed revision of the attributions of the Parthian coins struck during the so-called 'Dark Age' and its historical significance." East and West 51.1-2, 69108.

-. 2009. "The coinage of the so-called Parthian 'Dark Age' revisited.” Electrum 15, 141-194.

Sinisi, F. 2014. "Sources for the history of art of the Parthian period: Arsacid coinage as evidence for continuity of imperial art in Iran." Parthica 16, 9-60.

Strootman, R. 2017. “Imperial Persianism: Seleukids, Arsakids and Fratarakā.” In R. Strootman and M. J. Versluys (eds.), Persianism in antiquity, 177-200. Stuttgart: Franz Steiner.

Strugnell, E. 2008. “Thea Musa, Roman Queen of Parthia.” Iranica Antiqua 43, 275-298.

Van der Spek, R. J. 1998. "Cuneiform documents on Parthian history: The Rahimesu archive.” In Wiesehöfer (1998), 205-258.

Vardanyan, R. 2000. “Zur Deutung des Königsprofils auf parthischen Münzen.” Archäologische Mitteilungen aus Iran und Turan 32, 253-259.

-. 2001. "Tendenze culturali e ideologiche nell'impero partico riflesse dalla monetazione." Parthica 3, 25-132.

Widengren, G. 1983. "Sources of Parthian and Sasanian history." In E. Yarshater (ed.), The Cambridge history of Iran. Vol. 3.2, 1261-1283. Cambridge: Cambridge University Press.

Wiesehöfer, J. 1996. “'King of Kings' and 'Philhellên': Kingship in Arsacid Iran.” In P. Bilde (ed.), Aspects of Hellenistic kingship, 55-66. Aarhus: Aarhus University Press.

-. 1999. Das frühe Persien: Geschichte eines antiken Weltreichs. Munich: C. H. Beck.

-. 2007. "Fars under Seleucid and Parthian rule." In V. S. Curtis and S. Stewart (eds.), Age of the Parthians, 37-49. London: I. B. Tauris.

-. 2011. "Frataraka rule in Seleucid Persis: A new appraisal.” In A. Erskine and L. Llewellyn-Jones (eds.), Creating a Hellenistic world, 107-122. Swansea: Classical Press of Wales.

-. 2016. "Greeks, Iranians and Chinese on the Silk Road." In S. N. C. Lieu and G. B. Mikkelsen (eds.), Between Rome and China: History, religions and material culture of the Silk Road, 1-17. Turnhout: Brepols.

Wiesehöfer, J., ed. 1998. Das Partherreich und seine Zeugnisse / The Arsacid Empire: Sources and documentation. Stuttgart: Franz Steiner.

Wiesehöfer, J., and S. Müller, eds. 2017. Parthika: Greek and Roman authors' views of the Arsacid Empire / Griechisch-römische Bilder des Arsakidenreiches. Wiesbaden: Harrassowitz.

Wissemann, M. 1982. Die Parther in der augusteischen Dichtung. Frankfurt: Peter Lang.

Wolski, J. 1946. “Arsaces II.” Eos 41, 156-165.

-. 1965. "Le rôle et l'importance des mercenaires dans l'état Parthe." Iranica Antiqua 5, 103-115.

-. 1981. “L'aristocratie foncière et l'organisation de l'armée parthe.” Klio 63, 105-112.

-. 1993. L'empire des Arsacides. Leuven: Peeters.

Zanous, H. P., and J. Yang. 2018. "Arsacid cities in the Hanshu and Houhanshu." Iran and the Caucasus 22.2, 123-138. 
